\title{
Risky Human Capital and Alternative Bankruptcy Regimes for Student Loans *
}

\author{
Felicia Ionescu $^{\dagger}$
}

November 2010

Department of Economics, Colgate University, 13 Oak Dr, Hamilton, NY, 13346, USA.

\begin{abstract}
I study the implications of various bankruptcy regimes for student loans on college investment, human capital accumulation, and earnings in a heterogeneous life-cycle economy with risky human capital investment. The option to discharge one's debt under a liquidation regime helps alleviate some of the risk of investing in human capital. However, dischargeability triggers exclusion from borrowing and wage garnishment. Replacing liquidation with reorganization induces significant allocational consequences across education groups. Poor high school graduates with low levels of college preparedness are better off under liquidation, whereas high school graduates with high levels of assets and college preparedness are better off under reorganization. Overall, reorganization improves welfare by $1.2 \%$ relative to liquidation. However, an economy with partial dischargeability is desirable on welfare grounds.

JEL classification: D91; G33; I22

Keywords: Bankruptcy; Student loans; College risk; Human capital accumulation;
\end{abstract}

${ }^{*}$ Thanks to participants at the Macro Midwest Meetings, Midwest Economics Meetings, seminar series at Colgate University, Fordham University, University of Connecticut, University of Delaware, University of Western Ontario, and Macro Workshop of Liberal Arts Colleges, especially to Kartik Athreya, S. Chattarjee, Dean Corbae, Dirk Krueger, Lance Lochner, Igor Livshits, B. Ravikumar, Nicole Simpson, Chris Sleet, Jorge Soares, Gustavo Ventura, Galina Vereschgagina, Steve Williamson, Eric Young, and Christian Zimmermann.

†'Tel.: (315)228-7955; fax: (315)228-7033;

E-mail address: fionescu@mail.colgate.edu 


\section{Introduction}

The rapid rise in personal bankruptcy filing rates in the last decade with a peak of $9.15 \%$ in 2005 (as a \% of the U.S. adult population) centered attention on the nation's bankruptcy rule and filing behavior in the credit card market. In the same period, default rates for student loans averaged 12\% with the highest rate of $22.4 \%$ in 1990 (a two-year basis cohort default rate). Little attention has been given to analyzing bankruptcy rules in the student loan market and their impact on human capital accumulation. Yet, an understanding of how students respond to the incentives created by bankruptcy laws would help policy makers as they work to redesign the student loan program. This paper studies various bankruptcy regimes in the student loan market and their implications for repayment incentives and human capital investment.

More than 10 million people borrowed $\$ 66$ billion under the Federal Student Loan Program (FSLP) in fiscal year 2007.1 The risk associated with taking out a student loan and investing in college is far from being negligible. ${ }^{2}$ In addition, college students face a considerable amount of uncertainty after college (see Meghir and Pistaferri (2004) and Volkwein et al. (1998)). In the past, borrowers had the option to discharge their debt upon default to insure against these risks. However, high default rates in the late 1980s have led legislators to introduce a series of policy reforms that gradually made student loans nondischargeable, in switching from Chapter 7, a liquidation chapter in the Bankruptcy Code, to Chapter 13, a reorganization chapter. More recently, Congress passed a bill that allows for partial dischargeability. ${ }^{3}$ Available insurance mechanisms that dictate default incentives in student loans interact with students' characteristics that dictate human capital investment and work incentives both during and after college.

This paper studies the effects of these three bankruptcy rules (liquidation, reorganization and partial dischargeability) on default behavior and college investment, as well as their implications for life-cycle earnings and welfare across different groups of high school graduates. I develop a heterogeneous life-cycle economy where agents differ in initial ability, human capital stock and financial assets. Agents decide to invest in their human capital during college as well as after college, via on-the-job training. Their initial characteristics are tied to life-cycle human capital accumulation and earnings. In addition to family income, they may use loans under the FSLP to invest in college and consequently repay their student

\footnotetext{
${ }^{1}$ In the same year total unsecured debt amounted to $\$ 939$ billion.

${ }^{2}$ Using the PSID 1990, Restuccia and Urrutia (2004) find that $50 \%$ of people who enroll in college drop out. According to the NCES data, $36.8 \%$ and $35.2 \%$ of people enrolled in college in $89 / 90$ and $95 / 96$, respectively do not have a degree and are not enrolled 6 years after enrollment.

${ }^{3}$ Institutional details are provided in Section 2.
} 
loans after college. Students may also work during college. Agents have access to risk-free savings. This model builds on Ionescu (2009), who in turn generalizes the Ben-Porath (1967) human capital model to study college enrollment, borrowing and repayment behavior under the FSLP. Ionescu (2009) abstracts, however, from accounting for the risk of human capital investment and alternative bankruptcy arrangements, the focus of the current study.

The model is consistent with college enrollment and completion of high school graduates in the U.S. College students have higher levels of ability and initial human capital stocks, on average, than high school graduates who do not enroll in college. Also, college graduates have higher levels of ability and initial human capital stocks, on average, than college drop-outs. In addition, my findings suggest that ability drives the decision to enroll in college, while initial human capital stock is important for completing college. As a consequence of the diversity in human capital investment behavior across groups of students with different characteristics, the model produces earnings profiles by education groups consistent with the data. I use the model to conduct several revenue-neutral policy experiments. My contributions are threefold.

First, results suggest that the option to discharge one's debt helps reduce the risk of investing in college, even though this option comes with a cost. Discharging one's debt triggers exclusion from borrowing in the risk-free market and wage garnishment (details are provided in Section 2). In an economy where default and dischargeability is not allowed, enrollment in college declines by $1.9 \%$, with most of the decline coming from students with low levels of assets, high ability and medium levels of human capital. These are individuals who most likely take advantage of the option to discharge: they have relatively high levels of debt. In addition, their incentives to invest in human capital are high and thus dischargeability is valuable as it allows them to reallocate time to human capital after college. At the same time, the penalties upon default are not very severe; in particular, exclusion from borrowing does not hinder human capital investment, as these individuals can effectively use labor supply as an insurance device (unlike individuals with low human capital levels). Overall, dischargeability benefits college drop-outs.

Second, a reorganization bankruptcy rule significantly reduces default rates, from $20.8 \%$ under liquidation to $2 \%$ under reorganization and produces similar college enrollment and completion rates as liquidation. However, the effects differ across individuals: there is a shift in the distribution of college students such that the gap in characteristics between education groups shrink. Consequently, college drop-outs earn less under reorganization than under liquidation, whereas the opposite is true for college graduates. Overall people invest less in their human capital and earn slightly less over the life-cycle under reorganization. However, given that the cost of dischargeability is quite high, which in turn implies higher taxes in a liquidation regime, welfare increase by $1.2 \%$ in reorganization compared to liquidation. 
Under reorganization, individuals with low levels of human capital, ability, and assets, who typically do not enroll in college, are better off, whereas individuals with relatively high levels of ability, human capital and assets are worse off.

Finally, a policy that allows for income-contingent repayments and partial dischargeability that is restricted to financially constrained borrowers induces a $2.8 \%$ increase in welfare relative to liquidation. Poor students with low levels of ability and human capital benefit the most under this policy.

To conclude, while the option to discharge one's debt is quite valuable, replacing it with a delay in repayment and no restrictions to borrow in the risk-free market may substitute as an insurance mechanism against the risks college students face. However, a partial dischargeability regime may be desirable on welfare grounds. To this end, the results reveal important insights behind the interaction between student's characteristics and the available insurance mechanisms. These aspects are important when analyzing human capital investment and earnings across different education groups.

\subsection{Contribution to the Literature}

My model is motivated by empirical and theoretical work on how individual characteristics influence human capital accumulation and earnings over the life-cycle and how various insurance mechanisms help individuals hedge against risks that college educated individuals face. As such, this paper uses insights from two directions of study in the literature: human capital and bankruptcy.

\section{Related Human Capital Literature}

The first line of research has extensively explored the relevance of students' initial characteristics for human capital investment and the optimal policies for financially-constrained students. Starting in the early 1970s, it has been widely accepted that the decision to attend college is influenced by expected gains in lifetime earnings, which in turn are determined by unobservable characteristics (Willis and Rosen (1979) and Mincer (1974)). Ben-Porath (1967) and Becker (1964) are the first to recognize the importance of the complementarity between ability and human capital stock in explaining features of human capital accumulation and earnings dynamics. In addition, a large body of literature emphasizes the relevance of credit constraints for schooling decisions (see Cameron and Taber (2004), Carneiro and Heckman (2002) and Keane and Wolpin (2001)). My model recognizes the importance of both observable and unobservable characteristics regarding college investment.

Furthermore, the Ben-Porath model distinguishes between potential and actual earnings 
and provides a framework for testing the relationship between earnings and schooling. Mincer (1997) provides persuasive evidence for the validity of the human capital interpretation of the wage profile in the Ben-Porath model. Mincer also shows the importance of modeling human capital investment both in college and after. His findings are echoed in several recent papers (see Ehrlich and Kim (2007), Heckman et al. (2003) and Rubinstein and Weiss (2006)). Furthermore, recent studies summarized in Heckman et al. (2003) document that most of the human capital investment takes place at the beginning of the life-cycle during the schooling period and it is followed by subsequent learning during the life-cycle as on the job training. Huggett et al. (2006) demonstrate that the distribution of initial conditions is central to quantifying changes in schooling decisions driven by education policy. They show that the U.S. earnings distribution dynamics can be matched by the Ben-Porath model using the right joint distribution of ability and human capital. My model accounts for these features by linking unobserved characteristics to human capital investment and work decisions both during and after college.

An important observation in the literature is that college investment is risky (see Chatterjee and Ionescu (2010), Garriga and Keightley (2007) and Restuccia and Urrutia (2004)). College preparedness and school effort during college are important determinants of college graduation (see Cunha et al.(2006) and Manski(1983)). In addition, numerous studies document that students who work during college are more likely to drop out (see GAO (2003), L. Berkner and Cataldi (2002), Braxton et al. (2003), Cabrera et al. (1993) and Stinebrickner and Stinebrickner (2008)). The majority of students drop out from college later rather than sooner.4 Thus, unlike an environment where the possibility of dropping out from college is not modeled (or is exogenously given as in Caucutt and Kumar (2003) and Restuccia and Urrutia (2004)), allowing for the choice to allocate time to work versus human capital investment during college is important when accounting for the risk of dropping out from college. Furthermore, even in the case students graduate from college, there is high uncertainty in job prospectives after college. Meghir and Pistaferri (2004) estimate income processes for different education groups and find a relatively high variance for college graduates. This is consistent with the idea that the higher returns emanating from increased education come at the cost of higher earnings risk. Lastly, Cunha et al. (2005) show that $40 \%$ of the variability in the returns to schooling is not forcastable at the time when schooling decisions are made, implying that this uncertainty is not due to differences in initial characteristics by the time students decide to go to college.

My modeling takes into account these aspects by assuming that there is uncertainty in income after college and the dropout risk is contingent on the human capital accumulated

\footnotetext{
${ }^{4} \mathrm{My}$ empirical findings provide further evidence for these statements (See the Appendix for details).
} 
during college years. This human capital, in turn, depends on the student's initial characteristics and the time she allocates to college investment, in line with recent research by Garriga and Keightley (2007), Johnson (2009), and Chatterjee and Ionescu (2010). The first two papers emphasize the importance of the relationship between dropout risk and work during college, whereas the third paper emphasizes the relationship between dropping out and school effort. In addition, these studies recognize that students may also choose to drop out 5 However, they do not study the role of default under various bankruptcy arrangements to hedge against the risks that college students face.

Finally, my model captures the correlation between initial human capital, ability and assets. This approach is motivated by two main observations in the literature: 1) lower income people have less human capital built up by the time they enroll in college, and 2) the skills, ability and human capital acquired by the time the high school graduate decides to pursue college education are far more important for college completion than parental income in the college-going years (see Cameron and Taber (2004), Carneiro and Heckman (2002), Cunha and Heckman (2009), and Stinebrickner and Stinebrickner (2009)). Given that college completion is a key ingredient in the current setup and that college preparedness is the main factor for the chances to graduate, the correlation between these characteristics proves to be crucial in the current study.

\section{Related Bankruptcy Literature}

Research on bankruptcy has focused on personal bankruptcy laws and their implications for filing rates, with significant contributions by Athreya (2002), Chatterje et al. (2007) and Livshits et al. (2007). The two first studies explicitly model a menu of credit levels and interest rates offered by credit suppliers with the focus on default under Chapter 7 within the credit card market. The third study quantitatively compares liquidation in the U.S. to reorganization in Germany in a life-cycle model with incomplete markets, earnings and expense uncertainty. They find that the difference in consumer bankruptcy laws between Germany and the United States is consistent with the different levels of uncertainty faced by households in the two countries. In particular, in the U.S., negative income shocks are an important cause of discharging one's debt, and thus Chapter 7 benefits U.S. households. Sullivan et al. (2001) also document that over two-thirds of borrowers filing for bankruptcy in the U.S. have recently experienced a job disruption. In addition, research documents that an increased idiosyncratic income risk has been experienced by US households over the last 30 years (see Athreya et al. (2009) and Krueger and Perri (2006)). As mentioned, this risk

\footnotetext{
${ }^{5}$ In the current paper, I abstract from this feature given the complexity of the decision problems in the model.
} 
is considerably high for individuals who enroll in college. Thus, it is important to account for this source of risk in my model, in addition to the risk of dropping out of college.

The consensus in the literature is that in addition to institutionalized mechanisms that spread risks across individuals, self-insurance mechanisms such as labor supply and riskfree savings are the most obvious instruments to hedge against idiosyncratic shocks (see Heathcote et al. (2009)).6 Ignoring one of these two channels may exaggerate the quantitative importance of default for student loans. Thus, in my model, I allow for self-insurance via savings and labor supply along with bankruptcy for student loans. Of course, additional insurance mechanisms exist in realty, such as sophisticated financial instruments and risk-sharing within a range of networks including families, friends, firms and unions. Fully structural incomplete-markets models have been developed that explicitly incorporate a variety of such insurance mechanisms (See Heathcote et al. (2009) for an excellent survey of this literature) 7

The literature has ignored the relationship between human capital investment and default incentives. Exceptions include work by Lochner and Monge (2010) and Ionescu (2009). The first paper studies the interaction between borrowing constraints, default, and investment in human capital in an environment based on the U.S. Guaranteed Student Loan Program 8 and private markets where constraints arise endogenously from limited repayment incentives. The second paper quantifies the effects of repayment flexibility (such as to lock-in interest rates or to switch repayment plans) and the relaxation of eligibility requirements for student loans on college enrollment and default rates in an environment based on the FSLP. Both of these studies, however, abstract from modeling the risk of college education, as well as work during college. Furthermore, they do not capture a correlation between financial assets and unobserved characteristics. Finally, they do not analyze the incentives created by alternative bankruptcy regimes, which proves to be key for the analysis of human capital investment, as my findings reveal.

The paper is organized as follows: Section 2 provides institutional details about the bankruptcy rules for student loans. Section 3 describes the model and Section 4 the parametrization procedure. The results are presented in Section 5, and Section 6 concludes. A full

\footnotetext{
6 For instance, Attanasio et al. (2005) show that additional uncertainty increases female participation rates in a household. This effect on participation is greatest when the ability to borrow (and hence to smooth consumption) is limited.

${ }^{7}$ More related to the current paper are studies that account for the role of risk-sharing within family for young adults. Kaplan (2009) shows that the youth are more likely to move back in with their parents if they become unemployed. In a study on the role of borrowing constraints for college attainment, Johnson (2009) accounts for parental transfers for college students both during college (as in the current paper) and after college, depending on the job outcome of the student. The paper abstracts, however, from modeling other insurance mechanisms such as bankruptcy arrangements for student loans.

${ }^{8} \mathrm{GSL}$ is the former FSLP with a different set of rules upon default.
} 
description of the data is provided in the Appendix.

\section{Bankruptcy under the FSLP}

Under the FSLP students start to repay their loans six month after graduation. The interest rate on student loans is set by the government and it is based on the 91-day Treasury-bill rate. Borrowers start repaying under the standard plan that assumes payments for 10 years. 9

Students who participated in the Federal Loan Program before 1990 could file for bankruptcy under Chapter 7, "The Liquidation Chapter", without any restrictions and could discharge their loans. After a series of reforms, however, students now file for bankruptcy under Chapter 13, "Adjustment of the Debts of an Individual With Regular Income", one of the reorganization chapters under the Bankruptcy Code. Rather than a disposal of the assets through liquidation sale, the purpose of the reorganization chapters is to preserve and protect the integrity of the assets from the claims of creditors, so as to permit the debtor an opportunity to reorganize and restructure his assets and liabilities. The debtor enters a repayment plan. The indebted defaulter is required to reduce consumption to finance at least partial repayment of his obligations. Currently the only basis for obtaining a discharge is "undue hardship". 10

An important observation is that after the reforms in the 1990s, default on student loans does not mean default in the traditional sense. Under the current reorganization regime, default simply represents a delay in repayment that triggers a cost. If borrowers do not make any payments within 270 days in the case of a loan repayable in monthly installments or 330 days in the case of a loan repayable in less frequent installments, borrowers are considered in default, unless an agreement with the lender is reached (Section 435(i), Title IV of the Higher Education Act). The line of credit towards the private creditor is shut down and the loan is transferred to collection agencies. There are several consequences to default, some of which existed under the liquidation regime, and some of which have been implemented since then. Consequently, default incentives are affected. Data from the Department of Education show that the average two-year cohort default rate was $20.3 \%$ in $1987-1990$, whereas in 2005 it was $4.5 \% .11$

\footnotetext{
${ }^{9}$ Borrowers can switch to a different repayment plan. In the current study I abstract from modeling other repayment options to analyze the impact of the default option in isolation under alternative bankruptcy regimes. For a study on repayment options, see Ionescu (2008).

${ }^{10} \mathrm{As}$ a practical matter, it is very difficult to demonstrate undue hardship unless the defaulter is physically unable to work.

${ }^{11}$ U.S. Department of Education uses a two-year basis cohort default rate (CDR) as a primary measure (the percentage of a cohort of borrowers who are in default two-years after entering repayment). Source: http://www2.ed.gov/offices/OSFAP/defaultmanagement/defaultrates.html
} 
I model the liquidation regime in the benchmark economy and then conduct policy experiments to analyze the effects of dischargeability. I model the consequences of default to mimic those in the data under each of the two bankruptcy regimes. There are several common penalties to the two regimes: garnishment of defaulters' wages, seizure of federal tax refunds, possible hold on transcripts, ineligibility for future student loans, and bad credit reports to credit bureaus. 12 There are also three important differences in the consequences to default, outlined as follows:

First, the loan is discharged under liquidation and assets are seized, whereas under reorganization a repayment plan is implemented and assets are protected. Under reorganization, debt can increase by as much as $25 \%$ of the principle at the time when default occurs. Volkwein et al. (1998) reveal that the majority of defaulters reported making payments since the official default first occurred. In practice, the enforcement mechanism for repayment after default occurs is achieved through IRS tax witholdings (to be discussed below). Thus, I will not model repeated default under the reorganization regime.

Second, credit bureaus may be notified upon default, and credit ratings may suffer. In fact, according to the stipulations in the Bankruptcy Code, consumer reporting agencies may continue to report an account for 10 years (Chapter 7) or 7 years (Chapter 13) from the opening date. However, under reorganization, the negative credit report made by the Department is removed in the case where the defaulter successfully rehabilitates his loan. Based on the discussions with several financial aid agencies, defaulters usually enter repayment and rehabilitate their defaulted loans immediately after default occurs. 13 This action results in deleting the default status reported by the loan holder to the national credit bureaus, resulting in no restrictions to credit market participation. Thus, I will consider restrictions to credit market participation for 10 periods under the liquidation regime and only for the period when default occurs under reorganization.

Third, the Department of Education and student loan guaranty agencies are authorized to take ("garnish") a limited portion of the wages of a student loan debtor who is in default. The garnishment continues for several years under liquidation. The wage garnishment is interrupted, however, under reorganization once the defaulter rehabilitates his loan. In practice, this punishment varies across borrowers, depending on collection and attorney's fees, and can be as high as 10\%.14 This punishment is not imposed, however, if it would trigger financial hardship on the part of the defaulter. In practice, this means that the weekly

\footnotetext{
${ }^{12}$ Some of these penalties are justified by attorney and collections fees associated with delinquent borrowers. Institutions with high default rates are also penalized, but since I focus on the individual decision, this punishment is not captured in the current study.

${ }^{13}$ This fact is also documented in Volkwein et al. (1998).

${ }^{14}$ The Debt Collection Improvement Act of 1996 raised the wage garnishment limit to $15 \%$.
} 
Table 1: Bankruptcy rules under FSLP

\begin{tabular}{|c|c|c|}
\hline & $\begin{array}{c}\text { Chapter 7 - Liquidation } \\
\text { (before 1990) }\end{array}$ & $\begin{array}{c}\text { Chapter 13 - Reorganization } \\
\text { (under the current program) }\end{array}$ \\
\hline \hline Purpose & Disposal of the assets & Protection of the assets integrity \\
\hline Dischargeability & Allowed & Not allowed \\
\hline Cost & $\begin{array}{c}\text { Wage garnishment } \\
\text { Exclusion from credit markets } \\
\text { Seizure of tax refunds }\end{array}$ & $\begin{array}{c}\text { Wage garnishment } \\
\text { Debt increase } \\
\text { Seizure of tax refunds }\end{array}$ \\
\hline Benefit & Loans discharged & Bad credit report erased \\
\hline
\end{tabular}

income would be less than 30 times the federal minimum wage. In my model, I will adjust the garnishment relative to this threshold.

Under both regimes, the IRS can intercept any income tax refund that the defaulter may be entitled to until student loans are paid in full. In practice, very little is withheld since this penalty does not apply if the borrower is making payments under a negotiated repayment agreement or the loans were discharged in bankruptcy. Therefore, I abstract from modeling this punishment. These features of the two bankruptcy regimes are summarized in Table 1.

Finally, it is important to discuss reasons why borrowers may default on student loans. Nationally, borrowers of student loans indicate that the most important reasons for default are being unemployed (59\%) and working at low wages (49\%) (Volkwein et al. (1998)). Also, empirical evidence shows that default rates for student loans are declining in earnings and are increasing in college debt (see Dynarsky (1994), Ionescu (2008), Lochner and Monge (2010)). In a recent survey, Gross et al. (2009) document that college success as well as the background characteristics of the borrower (in particular college preparedness) play a big role in predicting default.

\section{Model}

The novelty of this model is that it simulates bankruptcy characteristics of the student loan market, which are very different than those of the credit card markets. Student loans are not secured by any tangible asset, so there might be some similarities with the unsecured credit market, but unlike credit cards, guaranteed student loans are uniquely risky, since the eligibility conditions are very different. Loans are based on financial need, not on credit ratings, and are subsidized by the government. Agents are eligible to borrow up to the full college cost minus expected family contributions. More importantly, unlike interest rates in other credit markets, the interest rate on student loans does not incorporate the risk that some borrowers might exercise the option to default. The feedback of any bankruptcy law 
into the interest rate is exactly how the default is paid for. I account for the default penalties similar to those implemented in the actual program, that might bear part of the default risk. This unique feature of the student loan market allows me to focus on default consequences under alternative bankruptcy regimes in a partial equilibrium setup where price effects are not accounted for. My analysis takes into account the limited size of the government budget.

\subsection{General Environment}

The environment is a life cycle economy with heterogeneous agents that differ in their immutable learning ability, $a$, human capital stock, $h$, and initial assets, $x$, which represent the family contribution to college. The set of these characteristics are jointly drawn according to a distribution $F(a, h, x)$ on $A \times H \times X$. Time is discrete and indexed by $j=1, \ldots, J$ where $j=1$ represents the first year after high school graduation. I model the decision of a high school graduate to invest in his college education by maximizing the expected present value of utility over the life-cycle

$$
\max E \sum_{j=1}^{J} \beta^{j-1} u\left(c_{j}\right),
$$

where $u($.$) is strictly concave and increasing, and \beta$ is the discount factor. The per period utility function is CRRA, $u\left(c_{j}\right)=\frac{c_{j}^{1-\sigma}}{1-\sigma}$, with $\sigma$ as the coefficient of risk aversion.

My model builds on the environment in Ionescu (2009), which, in turn generalizes the human capital model developed by Ben-Porath (1967). Ionescu (2009) allows for human capital accumulation in college. College costs can be financed by family contributions and student loans. I extend this previous work in several important ways. First, I account for the risk of not completing college. Thus, in the current setup, there are two distinct possible outcomes on the college path: one for college graduates and one for college dropouts. Second, I allow for working during college years, a key factor when accounting for the risk of dropping out of college. Human capital, however, is not productive during college years. Third, I introduce the possibility of discharging student loans. The liquidation regime is modeled in the benchmark economy and the reorganization regime is considered in the policy analysis. Additionally, environments where there is no default option or that allow for partial dischargeability are analyzed. College graduates and drop-outs default on their loans under alternative bankruptcy regimes. Fourth, agents may borrow in the risk-free market, which is an important assumption when modeling default penalties under various bankruptcy regimes where defaulters on student loans may or may not be restricted from borrowing in other markets. In addition, agents face idiosyncratic labor shocks, since income shocks represent an important ingredient in a model that studies the effects of the possibility 
Figure 1: Timing of Decisions

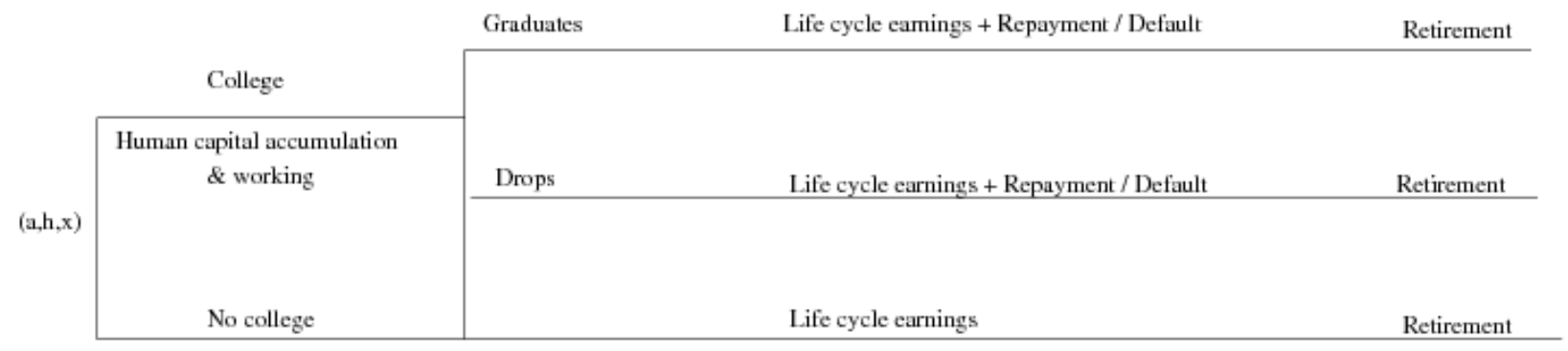

to discharge one's debt. Finally, I introduce a retirement phase, which is an important feature in a life-cycle economy with borrowing constraints and default option. 15

College graduates, college drop-outs and high school graduates who do not enroll in college optimally allocate time between market work and human capital accumulation. Human capital stock refers to "earning ability" and can be accumulated over the life-cycle, while learning ability is fixed at birth and does not change over time. I assume that the technology for human capital accumulation is the same during and after college and that human capital is not productive until graduation. Agents may save at the riskless interest rate. Additionally, agents who go to college optimally choose the repayment status for college loans. When deciding to go to college, agents may not have sufficient funds and may need to borrow to continue their education. College students may or may not acquire a college degree, but regardless of college graduation, they start repaying their student loans after college. A description of the timing in the model is provided in Figure 1.

The optimal life-cycle problem is solved in two stages. First, for each education group, I solve for the optimal path of consumption, time allocation, and human capital investment. In the case of college graduates and college drop-outs, I also solve for optimal repayment decision rules. Individuals then select between college and no college to maximize expected lifetime utility accounting for the risk of not graduating from college.

\subsection{Agent's Problem: No-College}

Agents who choose not to go to college maximize the expected present value of utility over their lifetime by dividing available time between market work and human capital accumulation and by saving during the working phase of their life-cycle. During the retirement phase, consumers simply face a consumption/savings decision. Their problem is identical to the one described in Ben-Porath (1967) with the exception of savings, idiosyncratic income shocks

\footnotetext{
${ }^{15}$ Without retirement the model overstates the role of default arrangements since borrowers may be too close to their borrowing constraints.
} 
during the working phase, retirement, and risk aversion.

Agents derive utility from consumption each period. During the working phase, $j=$ $1, \ldots, R-1$, earnings are given by the product of the stochastic component, $z_{j}$, the rental rate of human capital, $w_{j}^{n c}$, the agent's human capital, $h_{j}$, and the time spent in market work, $\left(1-l_{j}\right)$. The idiosyncratic shocks to earnings each period, $z_{j}$ evolve according to a Markov process with support $Z=[\underline{z}, \bar{z}]$, where $\underline{z}$ represents a bad productivity shock and $\bar{z}$ represents a good productivity shock. The Markov process is characterized by the transition function $Q_{z}$ and it is assumed to be the same for all agents. Agents may borrow/save at the riskless interest rate, $r_{f}$. Current savings are $x_{j+1}$. The initial assets, $x_{1}>0$, include the parental contribution to college. The depreciation rate of human capital is $\delta_{n c}$. Human capital production, $f\left(h_{j}, l_{j}, a\right)$, depends on the agent's learning ability, $a$, human capital, $h_{j}$, and the fraction of available time put into human capital production, $l_{j}$. Following BenPorath (1967), this is given by $f(h, l, a)=a(h l)^{\alpha}$ with $\alpha \in(0,1)$. The rental rate evolves over time according to $w_{j}^{n c}=\left(1+g_{n c}\right)^{j-1}$ with the growth rate, $g_{n c}$. During the retirement phase, $j=R, . ., J$, agents consume and save.

I formulate the problem in a dynamic programming framework and solve for the problem backwardly. In the last period of life, agents consume their savings. The value function in the last period of life is set to $V_{J}^{R, N C}(a, h, x)=u(x)$. For the retirement phase, the value function is given by

$$
\begin{aligned}
V_{j}^{R, N C}(a, h, x)= & \max _{x^{\prime}}\left[\frac{c^{1-\sigma}}{1-\sigma}+\beta V_{j+1}^{R, N C}\left(a, h, x^{\prime}\right)\right] \\
& \text { where } c=\left(1+r_{f}\right) x-x^{\prime} \text { for } \mathrm{j}=\mathrm{R}, . ., \mathrm{J}
\end{aligned}
$$

I use $V_{R}^{R, i}(a, h, x)$ from the previous step as a terminal node and solve for the set of choices in the working phase, for which the Bellman equation is given by

$$
\begin{aligned}
V_{j}^{N C}(a, h, x, z)= & \max _{l, h^{\prime}, x^{\prime}}\left[\frac{(c)^{1-\sigma}}{1-\sigma}+\beta E_{z^{\prime}} V_{j+1}^{N C}\left(a, h^{\prime}, x^{\prime}, z^{\prime}\right)\right] \\
& \text { where } c=z w h(1-l)+\left(1+r_{f}\right) x-x^{\prime} \text { for } \mathrm{j}=1, \ldots, \mathrm{R}-1 \\
& l \in[0,1], h^{\prime}=h\left(1-\delta_{n c}\right)+a(h l)^{\alpha}
\end{aligned}
$$

The value function $V_{j}^{N C}(a, h, x, z)$ gives the maximum present value of utility at age $j$ from states $h, x$, and $z$, when learning ability is $a$. Solutions to this problem are given by optimal decision rules: $l_{j}^{*}(a, h, x, z), h_{j}^{*}(a, h, x, z)$, and $x_{j}^{*}(a, h, x, z)$, which describe the optimal choice of the fraction of time spent in human capital production, the level of human capital, and assets carried to the next period as a function of age $j$, human capital, $h$, ability, $a$, and 
assets, $x$ when the realized state is $z$. The value function, $V_{1}^{N C}(a, h, x)$, gives the maximum expected present value of utility if the agent chooses not to go to college from state $h$, when learning ability is $a$, and initial assets are $x$.

\subsection{Agent's Problem: College Graduates and Drop-outs}

Agents who wish to acquire a college degree maximize the expected present value of utility over their lifetime by dividing available time between market work and human capital accumulation. Agents also save/borrow using the risk-free assets. Additionally, they optimally choose the loan amount for college education and the repayment status for their college loan. They face two types of risks: dropping out from college and uncertainty in their earnings after college. The earnings risk is exogenously given. The college dropout risk, however, depends on the human capital stock at the end of college, which in turn is determined by the agent's decision to allocate time to human capital accumulation during college. There are several sources of financing college: family contributions for college, need-based loans and merit-based grants. Students may also use their labor income and savings during college to finance their college education. 16

During college, students may choose to work at the wage rate $w_{c o l}$, but their human capital is not productive until they leave college. Yet working during college diverts time from human capital accumulation and may increase students' chances to leave college years without acquiring a college. At the same time, college students have jobs that pay a low wage and do not necessarily value students' human capital stocks, nor do they contribute to human capital accumulation (Autor et al. (2003)). However, students of high ability may be hired in better paid jobs than students of low ability. Thus, I model a wage rate per time units worked in college, $w_{c o l}(a)$, instead of per efficiency units; this rate increases in the ability level of the student. This assumption prevents low-ability students to enroll in college only to enjoy earnings during college that are much higher than the earnings they would have earned had they not enrolled in college. I assume that the growth rate in earnings during college is 0 .

Agents are allowed to borrow up to $\bar{d}(x)$, which represents the full college cost minus the expected family contribution. They choose the loan amount, $d$, at the beginning of college. Each period while in college, they receive equal fractions of the loan, pay direct college expenses, $\hat{d}$, and receive a scholarship, $t(a)$, which increases in the agent's ability.

College investment is risky. If a student with initial human capital $h_{1}$ decides to acquire a college degree, the probability with which she succeeds is given by $\pi\left(h_{5}\left(h_{1}, a, l_{1, \ldots, 4}^{*}\right)\right)$. This

\footnotetext{
${ }^{16}$ For details on the sources of college financing in the U.S. see the Appendix.
} 
is a continuous, increasing function of the human capital stock after college years, $h_{5}$, which in turn increases in the initial human capital stock, $h_{1}$, the ability of the individual, $a$, and her choice of time devoted to human capital investment during college years, $l_{1, \ldots, 4}^{*}$. This formulation captures the idea that college preparedness, embodied in $h_{1}$, student's learning capacity, captured in $a$, as well as effort to invest in human capital during college are important determinants of college completion. If the student completes college, she will walk into period 5 as a college graduate, i.e. $i=c g$, and if she does not complete college, she will walk into period 5 as a college dropout, i.e. $i=c d .17$

After college, agents face income shocks; earnings are given by the product of the stochastic component of earnings, $z_{j}$, the rental rate of human capital, $w_{j}^{i}$, the agent's human capital, $h_{j}$, and the time spent in market work, $\left(1-l_{j}\right)$. The idiosyncratic shocks, $z_{j}$ have the same properties as before. Depending on whether agents graduate from college or not, they face different growth rates in the rental rate. The rental rate equals $w_{j}^{i}=\left(1+g_{i}\right)^{(j-1)}$ with $i \in\{c g, c d\}$ : the growth rate is given by $g_{c g}$ if students graduate and by $g_{c d}=g_{n c}$ if they drop out, with $g_{c g}>g_{n c} 18$ Agents derive utility from consuming each period and they save $x_{j+1}$. Their bankruptcy status is reflected by the payment they have chosen $p_{j} \in\left\{0, \bar{p}\left(d, r, T_{r}\right)\right\}$. In case they are in the repayment status, they pay $\bar{p}$, which represents a fixed payment based on the loan amount that they borrowed for college, $d$, the interest rate on student loans, $r$, and the time required for full payment, $T_{r}$. In the case borrowers default in period $j$, there is no payment. The interest rate on student loans, $r$, is deterministic and set by the government. As before, the stock of human capital increases when human capital production offsets the depreciation of current human capital. Human capital production, $f\left(h_{j}, l_{j}, a\right)$, is given by $f(h, l, a)=a(h l)^{\alpha}$ with $\alpha \in(0,1)$. I assume that the technology for human capital accumulation is the same during college years and during training periods after college and is given by $h_{j+1}=h_{j}\left(1-\delta_{c g}\right)+a\left(h_{j} l_{j}\right)^{\alpha}$. When agents drop-out from college, they face the same human capital production function as under the no college path, given by $h_{j+1}=h_{j}\left(1-\delta_{c d}\right)+a\left(h_{j} l_{j}\right)^{\alpha}$ with $\delta_{c g}>\delta_{c d}=\delta_{n c}$.

As before, I formulate the agent's problem in a dynamic programming framework. Both problems for college graduates and drop-outs are solved in several steps starting backwardly.

${ }^{17}$ Modeling investment in four-year college and the risk of dropping out at the end of the 4 th period in the model are justified by data: according to the BPS 95/96, 68.5\% of students enroll in four-year colleges and they borrow more heavily (both in numbers and levels) relative to students who enroll in two-year colleges. My findings also show that $89 \%$ of college drop-outs are enrolled in college at least for 3 full years. Details are provided in the Appendix.

${ }^{18}$ The growth rates for wages are estimated from data. Evidence shows that college drop-outs and no college people have similar growth rates and lower than college graduates. Also, human capital depreciates faster for college graduates than for college drop-outs and individuals who do not enroll in college. See Section 4.1 for details. 


\section{Retirement phase, $j=R, . ., J$}

Agents face a consumption/savings problem. The value function in the last period of life is set to $V_{J}^{R}(a, h, x)=u(x)$. The Bellman equation is given by

$$
\begin{gathered}
V_{j}^{R}(a, h, x)=\max _{x^{\prime}}\left[\frac{c^{1-\sigma}}{1-\sigma}+\beta V_{j+1}^{R}\left(a, h, x^{\prime}\right)\right] \\
\text { where } c=\left(1+r_{f}\right) x-x^{\prime}
\end{gathered}
$$

\section{Working phase, $j=5, . ., R-1$}

I use $V_{R}^{R}(a, h, x)$ from the previous step as a terminal node and solve for the set of choices in this phase of the life-cycle. I further break down this phase into a post-repayment period and a repayment period.

1. In the post-repayment period, $j=T, . ., R-1$, agents consume, save and allocate time to market work and human capital accumulation. The Bellman equation is given by

$$
\begin{aligned}
V_{j}^{P P, i}(a, h, x, z)= & \max _{l, h^{\prime}, x^{\prime}}\left[\frac{c^{1-\sigma}}{1-\sigma}+\beta E_{z^{\prime}} V_{j+1}^{P P, i}\left(a, h^{\prime}, x^{\prime}, z^{\prime}\right)\right] \\
& \text { where } c=z w_{j}^{i} h(1-l)+\left(1+r_{f}\right) x-x^{\prime} \\
& l \in[0,1], h^{\prime}=h\left(1-\delta_{i}\right)+a(h l)^{\alpha}
\end{aligned}
$$

where $V_{j}^{P P, C D}$ represents the value function of college drop-outs and $V_{j}^{P P, C G}$ represents the value function of college graduates. Note that $j=T$ is endogenous. At period $T$, there is no more debt to repay, $d=0$. Period $T$ depends on the choice of the repayment/default status. Specifically, in the case where the borrower does not default, $T=5+T_{r}=15$; however, in the case where the agent decides to default on her loan, $T$ depends on the timing of this decision, denoted by $j^{\text {def }}$. Also $T$ differs across bankruptcy rules. Under liquidation, where dischargeability is allowed, $T=j^{d e f}+1$ and under reorganization, where dischargeability is not allowed and a repayment plan is implemented, $T=j^{\text {def }}+11$.

2. In the repayment period, $j=5, . ., T-1$ (with $T \leq T_{r}$ ), in addition to the choices in the previous problem, agents decide on their repayment/default status. I use $V_{T}^{P P, i}(a, h, x, z)$ from the previous step as a terminal node. The Bellman equation is given by

$$
\begin{aligned}
V_{j}^{i}(a, h, x, d, z)= & \max _{l, h^{\prime}, x^{\prime}, p, d^{\prime}}\left[\frac{c^{1-\sigma}}{1-\sigma}+\beta E_{z^{\prime}} V_{j+1}^{D, i}\left(a, h^{\prime}, x^{\prime}, d^{\prime}, z^{\prime}\right)\right] \\
& \text { where } c=z w_{j}^{i} h(1-l)+\left(1+r_{f}\right) x-x^{\prime}-p \\
& l \in[0,1], h^{\prime}=h\left(1-\delta_{i}\right)+a(h l)^{\alpha} \\
& d^{\prime}=(d-p)(1+r), p \in\{0, \bar{p}(d, r, T)\} .
\end{aligned}
$$


The value function $E_{z^{\prime}} V_{j+1}^{D, i}$, with $i=C G$ for college graduates and $i=C D$ for college drop-outs, accounts for the decision to repay or default, which is explained separately in Section 3.2.1. As mentioned at the end of this phase, the debt level is 0 .

College phase, $j=1, . ., 4$

I take into account the risk of dropping out from college and use $V_{5}^{C}(a, h, x, d, z)=$ $\pi\left(h_{5}\right) V^{C G}(a, h, x, d, z)+\left(1-\pi\left(h_{5}\right)\right) V_{5}^{C D}(a, h, x, d, z)$ as the terminal node to solve for the optimal rules. Agents invest in their human capital during college and they may decide to work. In the first period, they also choose the loan amount for college education, $d$, which will be equally divided in four rounds of loans during college years. Thus, I break this phase into two periods, the last three periods in college and the first period.

For $j=2, . ., 4$, the Bellman equation is

$$
\begin{aligned}
V_{j}^{C}(a, h, x, d)= & \max _{l, h^{\prime}, x^{\prime}}\left[\frac{c^{1-\sigma}}{1-\sigma}+\beta V_{j+1}^{C}\left(a, h^{\prime}, x^{\prime}, d\right)\right] \\
& \text { where } c=\left(1+r_{f}\right) x+w_{c o l}(1-l)+t(a)+d / 4-\hat{d}-x^{\prime} \\
& l \in[0,1], h^{\prime}=h\left(1-\delta_{c}\right)+a(h l)^{\alpha} .
\end{aligned}
$$

Lastly, for $j=1$, the Bellman equation is

$$
\begin{aligned}
V_{1}^{C}(a, h, x)= & \max _{l, h^{\prime}, x^{\prime}, d}\left[\frac{c^{1-\sigma}}{1-\sigma}+\beta V_{2}^{C}\left(a, h^{\prime}, x^{\prime}, d\right)\right] \\
& \text { where } c=\left(1+r_{f}\right) x+w_{c o l}(1-l)+t(a)+d / 4-\hat{d}-x^{\prime} \\
& l \in[0,1], h^{\prime}=h\left(1-\delta_{c}\right)+a(h l)^{\alpha} \\
& d \in D=[0, \bar{d}(x)] .
\end{aligned}
$$

Solutions to this problem are given by the optimal decision rules: the fraction of time spent in human capital production, $l_{j}^{*}(a, h, x, z)$, human capital, $h_{j}^{*}(a, h, x, z)$, and assets carried to the next period, $x_{j}^{*}(a, h, x, z)$, as a function of age, $j$, human capital, $h$, ability, $a$, assets, $x$, and college debt, $d$, when the realized state is $z$. For the repayment period, decision rules include optimal repayment choice, $p_{j}^{*}(a, h, x, d, z)$, for $j \geq 5$ and student loan amount, $d^{*}(a, h, x)$. The value function, $V_{1}^{C}(a, h, x)$, gives the maximum present value of utility if the agent chooses to go to college from state $h$ when ability is $a$ and initial assets are $x$. 


\subsubsection{Default}

As mentioned above, the value function in the right hand side of the Equation 6, which describes the repayment period, $E V_{j+1}^{D, i}$, with $i \in\{C G, C D\}$, accounts for the decision to repay or default. I will describe this problem starting with the period after default occurs and then present the value function during the period when default occurs. I will present each bankruptcy regime separately: liquidation, which is considered in the benchmark economy and reorganization, which is considered in the policy analysis. In the policy section, I discuss the implications of a regime that allows for partial dischargeability and the absence of a default option.

\section{Case 1: Dischargeability/Liquidation}

In this case there is no repayment in the period during which default occurs, $j^{\text {def }}$, and in any period thereafter. The consequences to default are modeled to mimic those in data: wage garnishment and exclusion from credit markets. This corresponds to a garnishment of a fraction $\rho_{L}$ of the earnings and the inability to borrow in the risk-free market for ten periods, $x^{\prime} \geq 0$. In addition, assets are seized during the period when default occurs. The wage garnishment is not imposed in the case where earnings are below a minimum threshold. $V_{A D L}^{i}$ represents the value function for ten periods after default occurs, $j=j^{\text {def }}+1, . ., j^{d e f}+10$ and $V_{j \text { def }}^{D L, i}$ represents the value function for the period in which default occurs. As before, $i \in\{C G, C D\}$.

$$
\begin{aligned}
V_{j}^{A D L, i}(a, h, x, z)= & \max _{l, h^{\prime} x^{\prime}}\left[\frac{c^{1-\sigma}}{1-\sigma}+\beta E_{z^{\prime}} V_{j+1}^{A D L, i}\left(a, h^{\prime}, x^{\prime}, z^{\prime}\right)\right] \\
& \text { where } c=z w_{j}^{i} h(1-l)\left(1-\rho_{L}\right)+\left(1+r_{f}\right) x-x^{\prime} \\
& l \in[0,1], h^{\prime}=h\left(1-\delta_{i}\right)+a(h l)^{\alpha}, x^{\prime} \geq 0 . \\
V_{j^{d e f}}^{D L, i}(a, h, x, d, z)= & \max _{l, h^{\prime}}\left[\frac{(c)^{1-\sigma}}{1-\sigma}+\beta E_{z^{\prime}} V_{j^{\text {def }}+1}^{A D L, i}\left(a, h^{\prime}, z^{\prime}\right)\right] \\
& \quad \text { where } c=z w_{j}^{i} h(1-l)\left(1-\rho_{L}\right)+\left(1+r_{f}\right) x-x^{\prime} \\
& d^{\prime}=0, l \in[0,1], h^{\prime}=h\left(1-\delta_{i}\right)+a(h l)^{\alpha}, x^{\prime}=0
\end{aligned}
$$

where $\rho_{L}>0$ if $z w_{j}^{i} h(1-l) \geq \underline{e}$ and $\rho_{L}=0$ otherwise. Due to "financial hardship", the defaulter is excused of the wage penalty, which in practice, is used to pay attorney costs.

A college graduate or dropout who has not defaulted on her student loans may choose to repay or default in the current period. Optimal repayment implies maximizing over the value functions that represent maintaining the repayment status and default in the current 
period. Define

$$
V_{j}^{D, i}(a, h, x, d, z)=\max _{p}\left[V_{j}^{i}(a, h, x, d, z), V_{j}^{D L, i}(a, h, x, d, z)\right]
$$

with $V_{j}^{i}$ the value function for repaying defined in Equation 6 above and $V_{j}^{D L, i}$, the value function for default.

With the appropriate parameters and the estimated Markov process for earnings shocks, I solve for optimal choices on each repayment status and then dynamically pick the optimal repayment choice, $p_{j}^{*}(a, h, x, d), \forall j=5, . ., J$. The problem delivers the optimal time for default, $j^{\text {def }}$.

\section{Case 2: Non-Dischargeability/Reorganization}

In this case the consequences to default include a wage garnishment during the period in which default occurs, given by the fraction $\rho_{R} \in(0,1)$, and an increase in the debt level at which the agent enters repayment in the next period, given by the fraction $\mu \in(0,1)$. Once the agent enters repayment, it is assumed that she will never default again, in line with the data (see Section 2). The bad credit reports are erased and the defaulter is not restricted from borrowing in the risk-free market once she starts repaying her loan. $V_{j}^{A D R, i}$ represents the value function for ten periods after default, $j=j^{d e f}+1, \ldots, j^{d e f}+10$, when repayment is required

$$
\begin{aligned}
V_{j}^{A D R, i}(a, h, x, d, z)= & \max _{l, h^{\prime} x^{\prime}}\left[\frac{c^{1-\sigma}}{1-\sigma}+\beta E_{z^{\prime}} V_{j+1}^{A D R, i}\left(a, h^{\prime}, x^{\prime}, d^{\prime}, z^{\prime}\right)\right] \\
& \text { where } c=z w_{j}^{i} h(1-l)+\left(1+r_{f}\right) x-x^{\prime}-p \\
& d^{\prime}=(d-p)(1+r) \\
& l \in[0,1], h^{\prime}=h\left(1-\delta_{i}\right)+a(h l)^{\alpha} .
\end{aligned}
$$

$V_{j^{d e f}}^{D R, i}$ represents the value function for the period in which default occurs. As before $\rho_{R}>0$ if $z w_{j}^{i} h(1-l) \geq \underline{e}$, and $\rho_{R}=0$, otherwise and $i \in\{C G, C D\}$.

$$
\begin{aligned}
V_{j^{d e f}}^{D R, i}(a, h, x, d, z)= & \max _{l, h^{\prime}}\left[\frac{c^{1-\sigma}}{1-\sigma}+\beta E_{z^{\prime}} V_{j^{d e f}+1}^{A D R, i}\left(a, h^{\prime}, z^{\prime}\right)\right] \\
& \text { where } c=z w_{j}^{i} h(1-l)\left(1-\rho_{R}\right)+\left(1+r_{f}\right) x-x^{\prime} \\
& d^{\prime}=d(1+\mu)(1+r), \\
& l \in[0,1], h^{\prime}=h\left(1-\delta_{i}\right)+a(h l)^{\alpha}, x^{\prime} \geq 0
\end{aligned}
$$


Similarly to the liquidation regime, a college graduate or dropout who has not defaulted on her student loans may choose to maintain the repayment status or default in the current period:

$$
V_{j}^{D, i}(a, h, x, d, z)=\max _{p}\left[V_{j}^{i}(a, h, x, d, z), V_{j}^{D R, i}(a, h, x, d, z)\right]
$$

with $V_{j}^{i}$ the value function for repaying defined in Equation 6 and $V_{j}^{D R, i}$, the value function for default.

\subsection{Government Budget Constraint}

My policy analysis takes into account the limited size of the government budget. In this economy the only role for the government is related to college financing. Consider first an economy where there is no default; the government expenditure consists of the present value of loans. In addition, the government subsidizes the interest rate, $r$ during college years. The government borrows in the risk-free capital markets at interest rate $r_{f}$. The interest rate on student loans out-weighs the interest rate in the risk free market. 19 The revenue from repayment is used to cover the cost associated with subsidizing the interest rate during college. However, this revenue may not suffice. To balance the budget, the government collects lump-sum taxes to finance the remaining cost. Taxes are paid by all consumers in the economy during each period in the working phase.

In an economy where there is default, there is an additional cost to the government. In the benchmark economy this cost mainly comes from the discharged debt. To finance it, the government uses additional lump-sum taxation; this implies higher taxes paid by consumers in the benchmark economy relative to a case where there is no default. In addition, there may be costs associated with attorney fees and judicial procedures. As in practice, the government covers this latter costs through wage garnishment imposed on defaulters. Recall that part of the defaulter's wage is garnished, provided that their wage is above the minimum threshold.

Let $\phi$ be the set of all agents who decide to go to college and take out student loans, $\Phi=\left\{k \in A \times H \times X\right.$ such that $V_{1}^{C}(k) \geq V_{1}^{N C}(k)$ and $\left.d^{*}(k)>0\right\}$. Let $\Phi_{\text {nodef }}$ be the subset of agents in $\Phi$ who choose not to default on their loans. The budget constraint is given by

$$
\int_{k \in \Phi} d^{*}(k) d k=\sum_{j=5}^{T} \beta^{j-1} \int_{k \in \Phi_{\text {nondef }}} p_{j}^{*} d k+\sum_{j=5}^{R-1} \beta^{j-1} t_{j} \int_{k} d k
$$

\footnotetext{
${ }^{19}$ Recall that the interest rate on student loans is based on the 91-day Treasury-bill rate plus a margin.
} 
The term in the left hand side represents the present value of loans. The right hand side consists of the present value of revenues: loan payments from nondefaulters and lump-sum taxes collected each period during the working phase from all consumers in the economy. Note that repayment starts at period 5; however there is no interest accumulated on student loans in the first four periods. As in practice, I assume that wage garnishments from defaulters cover the additional cost associated with attorney fees, ${ }^{20}$

In the reorganization regime, default simply means a delay in repayment. Given that there is no dischargeability, there is no cost to the government from discharged debt. In this respect, the economy is similar to the economy with no default. Similar to the benchmark economy, however, there is a cost associated with attorney fees. In addition, there is a cost associated with collection fees under reorganization. As in practice, the government recovers these costs through wage garnishment during the period where default occurs. In addition, recall that there is a penalty on the debt level after default occurs, which is justified by these judiciary and collection costs associated with delinquent borrowers. Consequently, the only role for taxation under the reorganization regime is to finance the subsidy of interest during college (similar to the economy without any default option). Thus, taxes in this economy are small compared to the benchmark economy. In my policy analysis in Section 5, I account for this difference in taxation between the benchmark economy and the reorganization economy. I also study an economy without the option to default and an economy that allows for partial dischargeability. These policies are also conducted under the budget neutral assumption.

\section{Parametrization}

I consider the liquidation bankruptcy rule in the benchmark economy. Thus, the model is calibrated to features of the student loan program in 1990. The parametrization process involves the following steps. First, I assume parameter values for which the literature provides evidence, and I set the human capital parameters to match the slope and decline of earnings by education groups using the Panel Study of Income Dynamics (PSID) data. For the policy parameters and the completion probability, I use data from the Department of Education. Second, I calibrate the stochastic process for earnings following the method in Storesletten et al. (2001), which is based on earnings from the PSID family files. The third step involves calibrating the joint initial distribution of assets, learning ability, and human capital. This is particularly challenging, given that there is no data counterpart. I extend the method used in Ionescu (2009) and proceed as follows: I use the 1990 BPS data for

\footnotetext{
${ }^{20}$ Since these two terms cancel each other out, I do not include either of them in the budget constraint in order to simplify exposition.
} 
expected family contributions (EFC) to estimate the two moments in the distribution of initial assets. Then, I find the joint distribution of unobserved characteristics by matching statistics of life-cycle earnings in the March Current Population Survey (CPS) for 1969-2002. Finally, I estimate the correlation between assets and unobserved characteristics to match college enrollment and completion rates by EFC groups in the 1990 BPS data set. The model period is one year.

\subsection{Parameters}

Table 2: Parameter Values

\begin{tabular}{|c|c|c|c|}
\hline Parameter & Name & Value & Target/Source \\
\hline \hline$\beta$ & Discount factor & 0.96 & real avg rate=4\% \\
\hline$\sigma$ & Coef of risk aversion & 2 & avg rate in 1994 \\
\hline$r_{f}$ & Risk free rate & 0.04 & avg rate in 1980-1996 \\
\hline$r$ & Interest on student loans & 0.056 & real life age 21-78 \\
\hline$J$ & Model periods & 48 & avg growth rate PSID \\
\hline$g_{c}$ & Rental growth for college & 0.0065 & avg growth rate PSID \\
\hline$g_{n c}$ & Rental growth for no college & 0.0013 & College Board \\
\hline$\delta_{c}$ & Depreciation rate for college & 0.0217 & decrease at end of life-cycle PSID \\
\hline$\delta_{n c}$ & Depreciation for no college & 0.0101 & decrease at end of life-cycle PSID \\
\hline$\alpha$ & Production function elasticity & 0.7 & Browning et. al. (1999) \\
\hline $\bar{d}$ & College cost & $\$ 22,643^{*}$ & College Board \\
\hline$\hat{d}$ & Tuition per college year & $\$ 2,977^{*}$ & DOE \\
\hline$T_{r}$ & Loan duration & 10 & Dept. of Education \\
\hline$\underline{e}$ & Minimum earnings upon default & $\$ 4,117$ & DOE \\
\hline$\mu$ & Debt increase upon default & 0.10 & \\
\hline
\end{tabular}

This is in 1982-1984 constant dollars.

The parameter values are given in Table 2. The coefficient of risk aversion chosen is standard in the literature and the discount factor is 0.96 to match the risk free rate of $4 \%$. McGrattan and Prescott (2000) provide a justification of the $4 \%$ number based on their measure of the return on capital and on the risk-free rate of inflation-protected U.S. Treasury bonds. ${ }^{21}$ Agents live 58 model periods, which corresponds to ages 21 to 78 . Statistics for lifetime earnings

${ }^{21}$ Alternatively, the discount factor and the risk free rate can be set to match the wealth-to-income ratio as in Storesletten et al. (2004) and similar studies that focus on consumption, earnings, and wealth inequality. However, given the complexity of the calibration procedure in other dimensions in my model (human capital investment, college risk, default, which are absent in these studies), I set the discount factor and the risk-free rate consistent with their findings. I run robustness checks on the discount factor in the economy (and allow it to be between 0.95 and 0.98 ). I find that results are not sensitive to the level of $\beta$. 
Figure 2: Statistics of Earnings by Education Groups: Data CPS

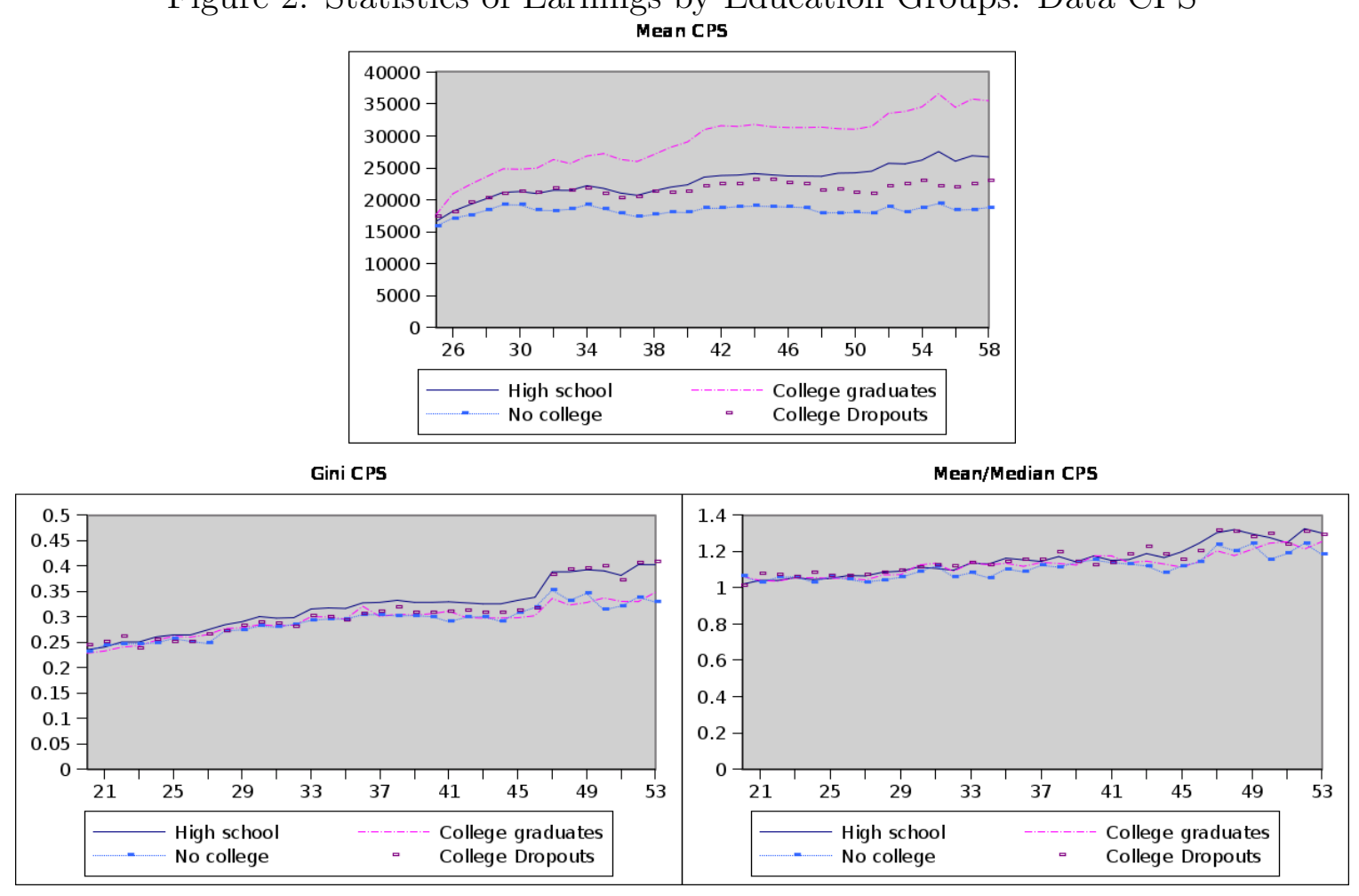

are based on earnings data from the CPS for 1969-2002 with synthetic cohorts. 22 Education groups are based on years of education completed with exactly 12 years for high school graduates who do not go to college, more than 12 years and less than 16 years of completed schooling for college drop-outs, and with 16 and 17 years of completed schooling for college graduates. ${ }^{23}$ Life-cycle profiles are given in Figure 2. The retirement phase lasts for 10 periods to match the lifetime expectancy for the cohort used from the CPS. ${ }^{24}$

The rental rate on human capital equals $w_{j}=(1+g)^{j-1}$, and the growth rate is set to $g_{c}=0.0065$ and $g_{n c}=0.0013$ respectively. I calibrate these growth rates to match the PSID data on earnings for high school graduates who do not have a college degree and college graduates. Given the growth rates in the rental rates, I set the depreciation rates to $\delta_{c}=0.0271$ and $\delta_{n c}=0.0101$, respectively, so that the model produces the rate of decrease of average real earnings at the end of the working life cycle. The model implies that at the end of the life cycle negligible time is allocated to producing new human capital and, thus,

\footnotetext{
${ }^{22}$ For each year in the CPS, I use earnings of heads of households age 25 in 1969, age 26 in 1970, and so on until age 58 in 2002. I consider a five-year bin to allow for more observations, i.e., by age 25 at 1969, I mean high school graduates in the sample that are 23 to 27 years old. Real values are calculated using the CPI 1982-1984. There are an average of 5000 observations in each year's sample.

${ }^{23}$ Education groups in the model are identified by years of schooling in the CPS data since information on the type of the degree obtained is not available.

${ }^{24}$ Source: http://www.infoplease.com/ipa/A0005148.html
} 
the gross earnings growth rate approximately equals $(1+g)(1-\delta) .25$

The wage rate during college is set to match average earnings of college students during college, given the average hours worked per year in college. According to the NCES data, $46 \%$ of full-time enrolled college students choose to work during college years. They work an average of 26 hours per week. According to the CPS, the annual mean earnings of 20 year old people who have some college education is $\$ 9,870$ in $1982-1984$ dollars. Thus, I estimate $w_{c o l}=\$ 15,208$. This is the earnings level for a student of median ability level. I further assume that earnings during college vary with the ability of the individual, such that the lowest ability student has a wage rate equal to the wage rate that individuals who do not enroll in college face during the first period on the job, $w_{1}$. Recall that the human capital of individuals who do not enroll in college is valued in the job market, whereas for college students it is not. Therefore I assume an increasing linear wage schedule such that high ability students earn more in college relative to low ability students. This formulation prevents the possibility that individuals with low ability and low human capital levels (given a positive correlation between them) enroll in college only to benefit from working at higher earnings that they would have not received otherwise.

I set the elasticity parameter in the human capital production function, $\alpha$, to 0.7. Estimates of this parameter are surveyed by Browning et al. (1999) and range from 0.5 to almost 0.9. This estimate is consistent with recent estimates in Huggett et al. (2006) and Ionescu (2009). 26

The probability of college completion, $\pi\left(h_{5}\right)$, is estimated to match completion rates by cumulative 1998 GPA scores in the Beginning Postsecondary Survey (BPS 95/96) data set for college students who enroll in four-year colleges during the academic year 1995-1996. Completion rate is defined as the fraction of students who have earned a bachelor's degree by June 2001. I use the GPA cutoffs for college completion in the data and the counterpart cutoffs of $h_{5}$ to estimate the probability of completing college in the model. Details are provided in the Appendix.

I set the penalties upon default as follows: in the benchmark economy (liquidation), agents are excluded from borrowing in the risk-free market for 10 years. This parameter is consistent with Livshits et al. (2007). I set the wage garnishment, $\rho=0.077$ to match the average two-year cohort default rate in 1987-1990, which is $20.3 \%$. Recall that this pun-

\footnotetext{
${ }^{25}$ When I choose the depreciation rate on this basis, the values lie in the middle of the estimates given in the literature surveyed by Browning et al. (1999). For details on the procedure and an extensive discussion for differential growth and depreciation rates by education groups see Ionescu (2009).

${ }^{26} \mathrm{I}$ assume the same elasticity parameter during college. When I relax this assumption and allow for a more productive human capital accumulation during college, the model delivers a much higher college premium in the model compared to the data.
} 
ishment is imposed only in the case where the defaulter's earnings are above a minimum threshold (30 times the federal minimum wage). Based on a minimum wage of $\$ 5.15$, this means that a minimum of $\$ 154.40$ (30 x $\$ 5.15)$ of the weekly wages is protected from garnishment. This translates into an annual minimum income of $\$ 4,117$ (in 1984 dollars). For the reorganization period, there is no exclusion from the risk-free market for periods after default occurs; instead there is an increase in the debt level upon default, which can be up to $25 \%$ of the debt level at the period when default occurs. Thus, in addition to the wage garnishment estimated to match the default rate under liquidation, I choose the increase in the debt level to be in the middle of the range $(\mu=0.10)$. I run robustness checks on this parameter and find that results are not sensitive to this increase in the debt level. The loan duration is set according to the Department of Education, $T_{r}=10$.

The interest rate on student loans is based on the average of the 91-day Treasury-bill rates for 1980-1996, adjusted for inflation plus a mark-up of 3.1\% as used by the Department of Education in the early 1990s. This delivers an interest rate of 5.6\%. The maximum loan amount is based on the EFC and the full college cost, $\bar{d}$, which is estimated as an enrollment weighted average (for public and private colleges). The same procedure is used to estimate

the direct cost of college (per year), $\hat{d}$. Finally, to set merit aid, $t(a)$, I use the Baccalaureate and Beyond (B\&B) 93/97 data set for college graduates from 1992-1993. I use the level of merit aid (as a percentage of college cost) across quartiles of SAT scores and set $t(a)$ across quartiles of ability in the model. Findings show that the level of merit aid increases in GPA and SAT quartiles, and thus $t(a)$ is an increasing function of $a$. Additional details on college costs, EFC and merit aid together with a description of the data sets used are provided in the Appendix.

\subsection{Stochastic Processes for Earnings}

In the parametrization of the stochastic idiosyncratic labor productivity process, I follow Storesletten et al. (2001) who build a panel from the PSID to estimate the idiosyncratic component of labor earnings. They use annual data from PSID from 1968 to 1991 for wage earnings and report separate values for different skill levels. With $u_{i j}=\ln \left(z_{i j}\right)$ the stochastic part of the labor income process for household $i$ at time $j$, the estimated model is: $u_{i j}=y_{i j}+\epsilon_{i j}$ and $y_{i j}=\rho y_{i, j-1}+\nu_{i j}$, where $\epsilon_{i j} N\left(0, \sigma_{\epsilon}^{2}\right)$ and $\nu_{i j} N\left(0, \sigma_{\nu}^{2}\right)$ are innovation processes. The variables $y_{i j}$ and $\epsilon_{i j}$ are realized at each period over the life cycle and are referred to as persistent and transitory "life-cycle shocks", respectively. The reported values are $\rho=0.935, \sigma_{\epsilon}^{2}=0.017$, and $\sigma_{\nu}^{2}=0.061$ for high school graduates. I have approximated this process as a two state Markov Chain, normalizing the average value for the idiosyncratic 
shock to be 1 . The resulting support is the set $Z=\{0.286,1.714\}$ with the transition probability matrix given by $\left[\begin{array}{ll}0.9455 & 0.0455 \\ 0.0455 & 0.9455\end{array}\right]$.

\subsection{The Distribution of Assets, Ability and Human Capital}

I estimate the joint distribution of initial assets, ability and human capital by accounting for correlations between all these three characteristics in the following way. First, for the asset distribution, I use the 1990 BPS data for EFC and set the mean to $\$ 9,585$ and the standard deviation to $\$ 10,798$ (in 1984 dollars). Second, I calibrate the initial distribution of ability and human capital to match key properties of the life-cycle earnings distribution in the US data and college enrollment and completion rates by initial asset levels. In order to carry out this procedure, I extend the method in Ionescu (2009), which in turn builds on the method in Huggett et al. (2006). I use the CPS 1969-2002 family files for heads of household aged 25 in 1969 and followed until 2002 for life-cycle earnings. Earnings distribution dynamics implied by the model are determined in several steps: i) I compute the optimal decision rules for human capital for all 3 education paths using the parameters described above for an initial grid of the state variable; ii) I account for the risk of college and solve for the enrollment decision and compute the life-cycle earnings for any initial pair of ability and human capital; and iii) I choose the joint initial distribution of ability and human capital to best replicate the properties of US data.

Using a parametric approach, I search over the vector of parameters that characterize the initial state distribution to minimize the distance between the model and the data statistics. I restrict the initial distribution on the two dimensional grid in the space of human capital and learning ability to be jointly, log-normally distributed. This class of distributions is characterized by 5 parameters. In practice, the grid is defined by 20 points in human capital and ability. I find the vector of parameters $\gamma=\left(\mu_{a}, \sigma_{a}, \mu_{h}, \sigma_{h}, \rho_{a h}\right)$ characterizing the initial distribution by solving the minimization problems $\min _{\gamma}\left(\sum_{j=5}^{J}\left|\log \left(m_{j} / m_{j}(\gamma)\right)\right|^{2}+\left|\log \left(d_{j} / d_{j}(\gamma)\right)\right|^{2}+\left|\log \left(s_{j} / s_{j}(\gamma)\right)\right|^{2}\right)$, where $m_{j}, d_{j}$, and $s_{j}$ are mean, dispersion, and inverse skewness statistics constructed from the CPS data on earnings, and $m_{j}(\gamma), d_{j}(\gamma)$, and $s_{j}(\gamma)$ are the corresponding model statistics. Overall, I match 102 moments. ${ }^{27}$ Figure A-1 in the Appendix illustrates the earnings profiles for high school graduates in the model versus CPS data when the initial distribution is chosen to best fit the three statistics considered. In my model, I obtain a fit of $9.8 \%(0 \%$ would be a perfect fit). The model performs well given college riskiness, stochastic earnings, and the institutional features that I account for in the current paper.28 The model pro-

\footnotetext{
${ }^{27}$ For details on the calibration algorithm see Ionescu (2009).

${ }^{28}$ For instance, Ionescu (2009) obtains a fit of $5.6 \%$ (for the same value of the elasticity parameter $\alpha=0.7$ ).
} 
Table 3: College Enrollment and Completion Rates by Assets

\begin{tabular}{|c|c|c|}
\hline Enrollment & Model & Data \\
\hline \hline Low & 34.9 & 34 \\
\hline Medium & 47.8 & 47 \\
\hline High & 51.8 & 62 \\
\hline \hline Completion & & \\
\hline \hline Low & 34.8 & 37 \\
\hline Medium & 47 & 45 \\
\hline High & 50.3 & 60 \\
\hline
\end{tabular}

Note: "low", represents the bottom quartile of EFC, "medium", represents the second and the third quartiles of EFC, and "high", represents the top quartile of EFC.

duces a correlation between ability and human capital of 0.77. Figure A-2 in the Appendix illustrates the marginal densities of ability and human capital.

Finally, I estimate the correlation between initial assets and ability, $\rho(a, x)$, and the correlation between initial assets and human capital stock, $\rho(h, x)$, to match enrollment and completion rates by asset levels (EFC) in the data. High school graduates are divided in three groups of initial assets: "low", which represents the bottom quartile of EFC, "medium", which represents the second and the third quartiles of EFC, and "high", which represents the top quartile of EFC. I compute enrollment and completion rates by these groups from the BPS data. I compute the model counterpart and jointly estimate correlations, $\rho(a, x)$ and $\rho(h, x)$, to match these 6 moments. The model produces $\rho(a, x)=0.75$ and $\rho(h, x)=0.3$. Table 3 shows enrollment and completion rates in the model and data. This approach is new in the literature and provides interesting insights on the importance of accounting for these correlations for human capital investment. Details are discussed in the next section.

\section{Results}

\subsection{Benchmark (Liquidation)}

The model does a good job in replicating the data with respect to college enrollment and completion rates as well as college premium and borrowing behavior. The model predicts that $46 \%$ of high school graduates enroll in college and $46.5 \%$ of students complete college in the benchmark economy. This compares to the CPS sample, which produces a college enrollment

As a measure of goodness of fit, I use $\frac{1}{3 J} \sum_{j=5}^{J}\left|\log \left(m_{j} / m_{j}(\gamma)\right)\right|+\left|\log \left(d_{j} / d_{j}(\gamma)\right)\right|+\left|\log \left(s_{j} / s_{j}(\gamma)\right)\right|$. This represents the average (percentage) deviation, in absolute terms, between the model-implied statistics and the data. 
rate of $47 \%$ and a college completion rate of $45 \% .29$ In the CPS sample (March 1969) college graduates represent $21 \%$ of the population. The model mimics this fraction, while delivering an average college premium of 1.62, in line with empirical estimates (Murphy and Welch (1992)). The model predicts that $78.5 \%$ of college students borrow to finance their college education and the average amount of student loan is $\$ 12,609$ (in 1982-1984 dollars). The data counterpart is between $54 \%$ and $66 \%$ for the borrowing percentage (depending on surveys) and $\$ 10,300$ for the loan amount. Consistent with the data, the majority of students do not borrow the maximum amount $(\$ 23,000)$. Approximately $20.6 \%$ of all borrowers default in the economy (recall that this moment is targeted in the calibration procedure).

\subsubsection{College Enrollment and Completion}

The model predicts that a combination of relatively high ability and relatively low human capital induces the decision to enroll in college. There is a trade-off between ability and human capital such that college represents a worthwhile investment. High ability agents have the incentive to devote most of their time early in life to human capital accumulation. This drives the decision of high ability agents to enroll in college, leading to higher enrollment rates for high ability agents. At the same time, agents with low levels of human capital have the incentive to devote most of their time to human capital early in life; human capital is not productive until the end of the college period. Also, the market values human capital and a low level of human capital stock implies a low opportunity cost of investing in college. These effects induce a high incentive to enroll in college for students with low human capital. However, there are two effects that counteract this incentive: low initial human capital implies a higher probability of not completing college and thus investing in human capital on the college path is more risky. In addition, ability and initial human capital stock are positively correlated in the model. Thus, people with relatively low human capital stock also have relatively low ability, which in turn implies lower rewards to college education. The opposite is true for students with high human capital levels: there is low risk to college investment, but the incentive to invest in college is relatively low. Consequently, the model delivers a U-shaped enrollment rates over initial human capital levels.

Overall, the combination of these effects deliver that agents who enroll in college have $2.4 \%$ more human capital, on average, and $7 \%$ more ability on average, relative to agents who choose not to enroll in college. Table 4 presents the statistics for initial characteristics across education groups.

\footnotetext{
${ }^{29}$ These numbers are consistent with data findings in Manski (1983). Also, according to the NCES data, $46 \%$ of high school graduates in 1964-1965 enroll in college.
} 
Figure 3: Earnings By Education Groups: Data vs Model

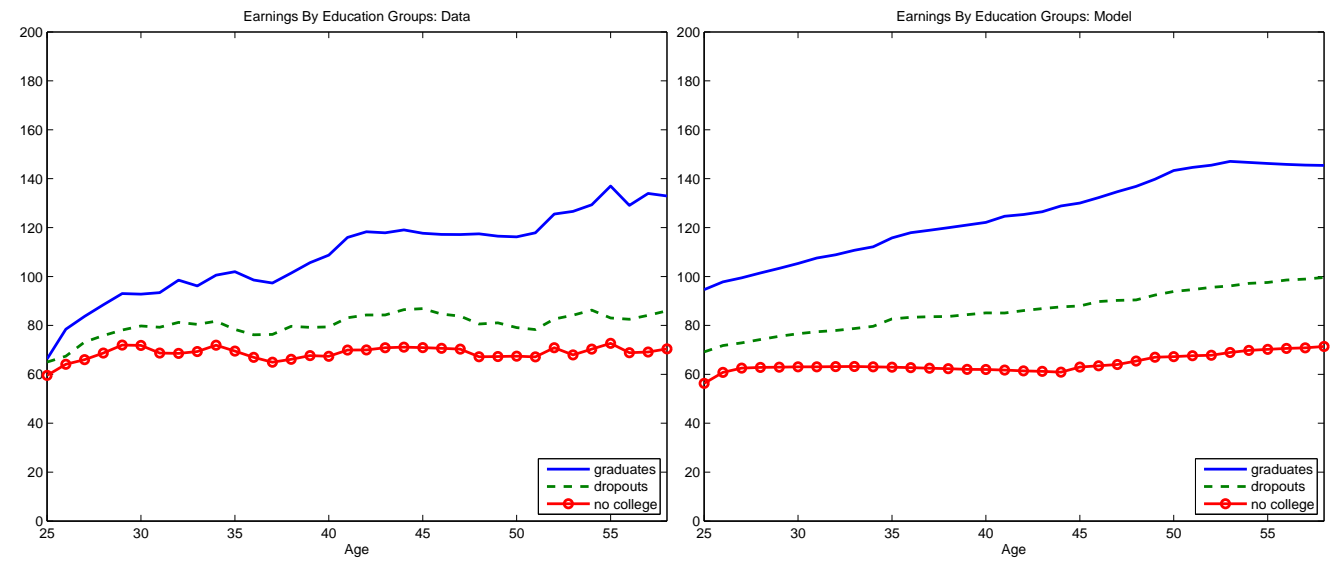

Table 4: Statistics of Initial Characteristics by Education Groups: Benchmark

\begin{tabular}{|c|c|c|c|c|}
\hline & No College & College Students & College Graduates & College drop-outs \\
\hline \hline Ability & $0.217(0.07)$ & $0.232(0.08)$ & $0.253(0.081)$ & $0.214(0.076)$ \\
\hline \hline Human Capital & $63(42)$ & $64.5(47)$ & $76.5(51.7)$ & $54(40.4)$ \\
\hline Assets & $8,700(10,200)$ & $10,500(11,400)$ & $11,700(12,300)$ & $9,400(10,200)$ \\
\hline
\end{tabular}

Note: The table presents the mean of the characteristic and standard deviation in parenthesis. For assets, figures are given in 1982-1984 dollars.

My results show that while both initial human capital and ability levels are important for college completion, the initial human capital stock plays the major role in graduating from college. The model predicts that college graduates have $18 \%$ higher levels of ability and $41.7 \%$ of human capital, on average relative to college drop-outs. College preparedness, which is embodied in the human capital stock of the high school graduate proves to be an important factor for college completion. This result is in line with empirical findings (Cunha and Heckman (2009) and Stinebrickner and Stinebrickner (2009)). Also, my findings are consistent with research by Hendricks and Schoellman (2009), who show that high ability students are more likely to stay in school. Given positive correlations between unobserved characteristics and initial assets, the model predicts that college students have $21 \%$ more initial assets compared to students who do not enroll in college. Also, college graduates have $24 \%$ more initial assets relative to college drop-outs.

As a result of the college enrollment and completion behavior, the model successfully replicates the observed life-cycle earnings profiles for the three education groups. Figure 3 shows the model predictions in the benchmark case for life-cycle earnings by education groups versus data (also see Figure 2 in the Appendix for more details on life-cycle earnings 
by education groups in the model versus data) 30 The schooling level determines the initial value of earnings as a result of human capital accumulated during college. Human capital accumulation after college determines the steepness of earnings profiles. Thus, the college group (who has a relatively high level of ability, on average) presents both a higher initial value of earnings and a steeper life-cycle earnings profile than the no college group. These predictions are in line with empirical research. Specifically, Mincer (1997) points out that while college education determines the starting position of the earnings profiles, the slope, peak and decline of earnings reflect the relative differences among workers in the amount, duration and depreciation of human capital gained through on-the-job training. 31 Furthermore, college students with relatively low ability and low human capital do not complete college. Human capital accumulation patterns for college drop-outs deliver a flatter profile of earnings for this group relative to college graduates, but a slightly steeper profile relative to people who choose not to enroll in college. College drop-outs do not accumulate enough human capital during college. They have a high incentive to invest in human capital on the job training. On average, the model predicts that college drop-outs have $14.3 \%$ less initial human capital relative to students who do not enroll in college and similar levels of ability, on average.

\subsubsection{The Importance of Correlating Assets with Human Capital and Ability}

The model captures correlation between initial human capital, ability and assets. In order to understand the importance of accounting for the correlation between initial assets and the individual characteristics in the current model, I conduct several experiments where I run robustness checks on the estimated correlations between assets and unobserved characteristics, keeping unchanged the other seven moments in the joint distribution of $(a, h, x)$.

My findings show that in the case where assets are independently drawn, i.e. $\operatorname{cor}(a, x)=0$ and $\operatorname{cor}(h, x)=0$, enrollment rates decline in initial asset levels and college completion rates are U-shaped in initial asset levels. These results are counterfactual: students from high income backgrounds are more likely to enroll and complete college than students from low income backgrounds (see Table 3). In the model, the possibility to discharge one's debt makes college an attractive financial investment for people with low initial assets. Without any correlation between assets and unobserved characteristics, the average assets level of college students is $50 \%$ of the average assets level of high school graduates who choose not to enroll. In the case I account only for the correlation between assets and human capital,

\footnotetext{
${ }^{30}$ Earnings levels are normalized such that the mean of earnings for high school graduates in the last period equals 100. This normalization translates into $\$ 30,000$ (1982-1984 dollars).

${ }^{31}$ Mincer also shows that roughly $75 \%$ of the (cross-sectionally) observed wage growth over the life cycle is attributable to job training or learning.
} 
the model delivers college completion rates consistent with the data; however, enrollment rates decline in initial asset levels. The opposite is delivered when I account only for the correlation between initial assets and ability.

Thus, a positive correlation between human capital and assets is key for delivering consistent completion rates by assets, whereas a positive correlation between ability and assets is important for delivering consistent enrollment rates by assets. In addition, the model implies that the correlation between ability and assets should be high enough relative to the correlation between human capital and assets in order to produce monotonic enrollment and completion rates by initial asset levels (see Table 3). The importance of these correlations are in line with research by Ehrlich and Kim (2007), who analyze the behavior of inequalities over economic development phases and show that this behavior depends on the correlation between ability, initial human capital stock, and financial wealth across family groups. Similar findings are provided in Cameron and Taber (2004), Cunha and Heckman (2009), and Keane and Wolpin (2001).

\subsubsection{Default Behavior: Implications for Life-Cycle Earnings}

Students have the option to default and discharge their debt; however, defaulters face wage garnishment and exclusion from borrowing. These effects vary across individuals with different characteristics. First, the option to discharge one's debt is particularly valuable for students with high debt levels and thus low initial asset levels. Also, the option is quite valuable for individuals who still find it optimal to invest in their human capital after college. Recall that these are the college students with relatively low levels of human capital or with relatively high levels of ability. The former group gives up less in terms of earnings in order to invest in human capital on the job training. For the latter, returns to college investment are considerably large. Second, the wage garnishment penalty is less severe for borrowers with low earnings. These are individuals with relatively low levels of ability and human capital. Third, the exclusion from borrowing plays an important role in the model as borrowing in the risk-free market provides college students with another insurance mechanism

against income risk. The absence of the possibility to smooth consumption via borrowing may reduce the incentive to allocate time to human capital over work. In the absence of borrowing, individuals use labor supply as an insurance device (see Heathcote et al. (2009)). However, this channel may not be effective for individuals with relatively low levels of human capital since the market value of their human capital is low. Thus, for them, the possibility to borrow in the risk-free market to smooth consumption is quite valuable. Quite opposite, individuals with relatively high levels of ability (and thus relatively high levels of human capital) may use the labor supply channel to buffer the negative impact of being restricted 
Table 5: Statistics of the Characteristics and Borrowing of Defaulters versus Non-defaulters

\begin{tabular}{|c|c|c|}
\hline Mean & Defaulters & Non-defaulters \\
\hline \hline Ability & $0.209(0.03)$ & $0.24(0.09)$ \\
\hline \hline Human Capital & $57.1(13.3)$ & $66.4(52.6)$ \\
\hline Assets & $54,600(2,670)$ & $11,820(12,300)$ \\
\hline
\end{tabular}

from borrowing.

As a result of the combinations of these incentives across individuals with different characteristics, the model predicts that college drop-outs are more likely to default than college graduates, a fact that is consistent with the data. The differences in default incentives, however, are not large. The default rate for college drop-outs is $20.7 \%$ and for college graduates, $20.5 \%$. On the one hand, college drop-outs have lower earnings, on average relative to college graduates, given the differences in ability and human capital stock levels between the two education groups. On the other hand, college drop-outs borrow slightly less on average relative to college graduates $(\$ 12,307$ versus $\$ 12,931)$. Borrowing and default behavior across education groups is consistent with the data.

Furthermore, findings show that in general defaulters are borrowers with relatively high debt and low earnings levels, which is in line with the data. Defaulters have on average, $46 \%$ of the asset levels of non-defaulters, which in turn implies higher levels of debt. Defaulters have, on average $87 \%$ of the levels of ability and $86 \%$ of the human capital of non-defaulters, which in turn imply lower earnings. Table 5 presents these predictions. Figure 4 illustrates the life-cycle earnings profiles by default status.

Defaulters earn $11 \%$ less, on average, over the life-cycle relative to non-defaulters. Note that college graduates have higher earnings compared to college drop-outs regardless of their default status. College graduates have higher levels of human capital and ability. An interesting observation is that college drop-outs who do not default have the lowest level of earnings out of all four groups. While the wage garnishment punishment is less severe for them, the opposite is true regarding the exclusion from the risk-free market punishment. As mentioned, this penalty is severe for people with low human capital. Thus, college dropouts who have relatively low levels of human capital do not default unless they have very high debt levels. Drop-outs who choose to default have relatively low levels of assets and relatively high levels of human capital compared to non-defaulters. Consequently, drop-outs who default have higher earnings profiles relative to drop-outs who do not default.

To this end, the interaction between student's characteristics that dictate time allocation incentives over the life-cycle and bankruptcy arrangements that dictate default incentives for student loans delivers diverse outcomes in human capital accumulation and earnings across 
Figure 4: Earnings Profiles for Defaulters versus Non-defaulters

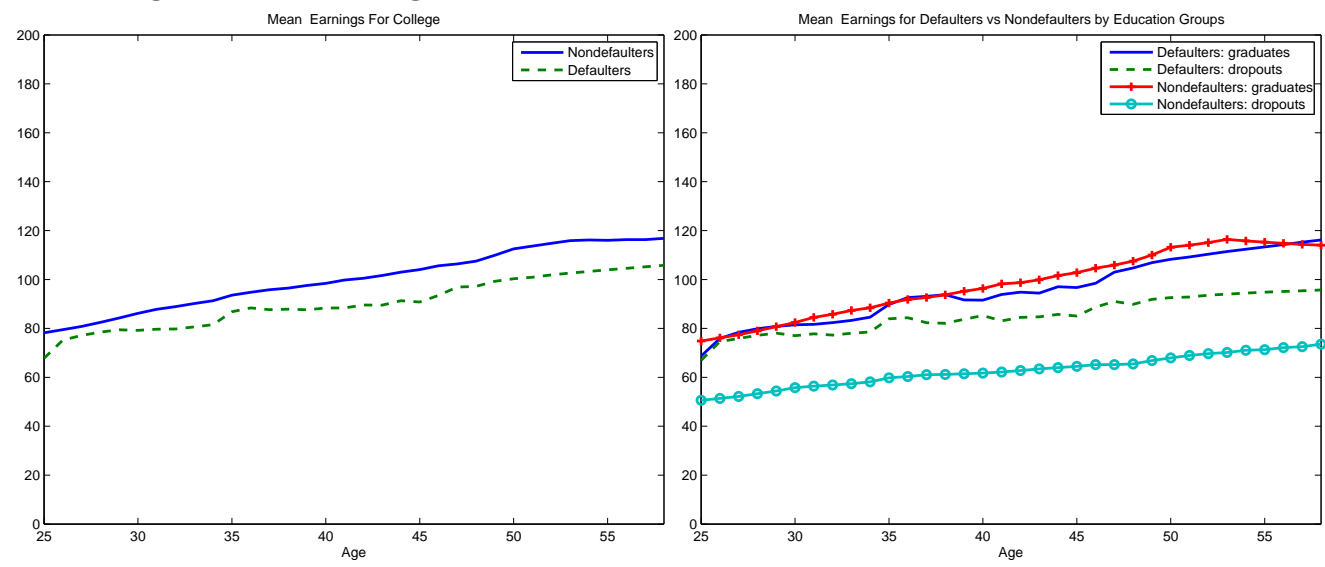

groups of students. Further insights about the implications of the possibility to discharge one's debt are discussed in the next subsection, where I do not allow for the option to default; at the same time, there will be no restrictions on market borrowing or wage garnishments.

\subsubsection{Counterfactual Experiment: No Default}

In an economy where default is not allowed, college enrollment decreases by 1.9 percentage points relative to the benchmark economy, where default is allowed under liquidation, from $45.9 \%$ to $44 \%$. The completion rate is similar to the benchmark level, such that the fraction of college graduates in the economy is just slightly lower. As expected, the amount borrowed is lower in this case: $\$ 9,961$ compared to $\$ 12,609$ in the benchmark economy.

The option to discharge one's debt upon default under liquidation proves to provide some insurance against the risk of investing in human capital, even though the option comes with a cost. The effects, however, differ across students with different characteristics. Enrollment rates decline for all groups of students, with the largest declines for: students in the top quartile of ability (-3.5\% relative to benchmark), students in the median quartiles (2 and 3) of human capital (-3\% relative to benchmark), and students in the lowest quartile of assets $(-3.2 \%$ relative to benchmark).

Students with relatively high ability find it worthwhile to keep investing in their human capital after college, given that they have high returns to college investment and dischargeability helps them divert time from work. This result reinforces the fact that, for them, the option to default and discharge their loans is quite valuable.

Students with medium levels of human capital are also affected to a large extent by the no-default policy relative to the benchmark economy. This group of students may still find it worthwhile to invest in their human capital after college. While this fact is also true for 
students with very low levels of human capital, for students with medium levels of human capital the penalties upon default under liquidation are not as strong as for other groups of students: their earnings are not high enough, and thus, the wage garnishment punishment is not very severe. At the same time, they are not very constrained in their earnings capabilities, and thus, exclusion from the risk-free market is not very costly.

As expected, students with low initial assets decide to enroll in college at much lower rates without the option to default relative to the benchmark economy. They have relatively high levels of college debt and the option to discharge one's debt is quite valuable for them.

As a consequence of these effects, the characteristics of individuals by education groups change: First, the gap between college and no college agents shrinks in terms of ability and asset levels. Second, human capital levels are $1.3 \%$ lower, on average, for college students relative to those with no college (compared to $2.4 \%$ higher under liquidation). As a result, earnings differ significantly by education groups relative to the benchmark economy. As expected, college drop-outs are the most affected, earning $4 \%$ less relative to the benchmark economy. This experiment strengthens the result that having the option to discharge one's debt is valuable especially for college drop-outs.

\subsection{Reorganization}

In this section, I present the effects of changing bankruptcy rules from liquidation to reorganization. There is a trade-off induced by the possibility to discharge one's debt (in the benchmark economy) relative to reorganization where repayment is required. Under reorganization, once the borrower starts repaying his debt in the following period after default, there is no wage garnishment and borrowing in the risk-free market is not restricted (as opposed to the benchmark economy, where these penalties last for 10 periods). However, the debt level at which the defaulter enters repayment in the following period increases under reorganization.

In my policy analysis, I account for the limited size of the government budget. Recall that given no cost associated with dischargeability under reorganization, the only cost to the government in this economy is associated with subsidizing interest rates during college. Thus taxes are lower under reorganization relative to the benchmark economy. My results deliver

a difference of $\$ 70$ in the per period and per capita tax (in 1982-1984 dollars) between the liquidation and the reorganization regimes. 


\subsubsection{College Enrollment and Completion}

Under reorganization, aggregate college enrollment and completion rates are similar to the benchmark level. This result implies that while the option to discharge one's debt is quite valuable, replacing it with a delay in repayment and no restrictions to borrow in the risk-free market may substitute as an insurance mechanism against the risks college students face. However, as a result of the different default incentives induced by the two bankruptcy regimes across different groups of people, there are significant allocational consequences regarding college enrollment, completion and life-time human capital accumulation.

My findings show that, under reorganization, a larger fraction of people with relatively low levels of ability and low levels of initial human capital enroll in college compared to the benchmark economy. At the same time, fewer people with relatively high ability and human capital levels enroll in college under reorganization. As mentioned, exclusion from the riskfree market under liquidation is particularly severe for students with low ability and human capital. Part of this effect may be counteracted by the fact that these borrowers also have low levels of assets and thus high levels of debt (given a positive correlation between student's characteristics and initial assets). Dischargeability is quite valuable for these individuals. In addition, reorganization is particularly severe for students with high debt levels given the increase in the debt penalty. Overall, the first effect dominates and a higher fraction of people from the bottom quartile of assets enroll in college compared to benchmark.

Given that college is risky, taking out a student loan may represent a riskier investment under the reorganization regime, in which debt cannot be discharged upon default. However, the possibility to borrow in the risk-free market more than compensates for this risk. Agents for whom the risk of failing from college is high will enroll in college in an environment where they have the possibility to keep investing in their human capital after college and hedge against income risk. While dischargeability on student loans offers some insurance against the income risk, the cost associated with exclusion from borrowing prevents college students from investing in their human capital later in life as they cannot afford to reduce their time allocation to work. Thus, these students are better off accumulating human capital on the no-college path under the liquidation regime. Consequently, the gap between the college group and the no-college group in terms of average initial assets and ability declines under reorganization. Also, in contrast to the benchmark economy, the college group has lower levels of initial human capital under reorganization relative to the no-college group. Lastly, the gap between college graduates and college drop-outs in terms of average ability and

human capital shrinks under reorganization. Table 6 presents average ability, initial human capital, and assets by education groups under reorganization. 
Table 6: Statistics of Initial Characteristics by Education Groups: Reorganization

\begin{tabular}{|c|c|c|c|c|}
\hline & No College & College Students & College Graduates & College drop-outs \\
\hline \hline Ability & $0.221(0.79)$ & $0.227(0.8)$ & $0.245(0.08)$ & $0.21(0.07)$ \\
\hline \hline Human Capital & $65.1(44)$ & $62.3(44)$ & $73.2(48)$ & $52.5(38.2)$ \\
\hline Assets & $9,300(11,100)$ & $9,900(10,500)$ & $10,800(10,950)$ & $9,120(9,600)$ \\
\hline
\end{tabular}

\subsubsection{Default Behavior: Implications for Life-Cycle Earnings}

Imposing reorganization and repayment after default induces a significant decline in the default rate: from $20.8 \%$ in the benchmark economy to $2 \%$ under reorganization. This compares to the cohort default rate of $4.5 \%$ in 2005 . Results suggest that the change in the bankruptcy rule induced most of the decline in the default rate since 1990.32

Results show that borrowers with very low levels of human capital, ability and assets default at higher rates under reorganization than under liquidation. Defaulters here have much lower levels of human capital and ability compared to defaulters under the liquidation regime. The non-dischargeability of loans together with the penalties upon default make the default option very costly under reorganization. Borrowers choose to default (i.e., delay their repayments) only if they are constrained in their capability of repayment. These are precisely the borrowers who have relatively low levels of ability and human capital, and thus have low earnings, as well as low asset levels, and high debt levels.

The model predicts that the gap in terms of characteristics between defaulters and nondefaulters is much larger under reorganization compared to the benchmark economy. In this economy, defaulters have $64 \%$ of the ability level of non-defaulters (compared to $87 \%$ in the benchmark economy); they also have $37 \%$ of the human capital stock of nondefaulters (compared to $86 \%$ under liquidation). Finally, defaulters have $26.4 \%$ of the initial assets of non-defaulters (compared to $46 \%$ in the benchmark economy). Table 7 presents these findings. These results imply that the debt-to-income ratio of defaulters is particularly high. The decision to default is driven by very low level of earnings and high indebtedness, results which are in line with empirical findings. As Figure 5 illustrates, defaulters earn $35 \%$ less relative to non-defaulters. They earn much less than college drop-outs in the economy and even less compared to high school graduates who do not enroll in college. Note that this latter result is driven by the relatively lower earnings level in the repayment period (i.e., the

\footnotetext{
${ }^{32}$ Other changes in the student loan program might have contributed to this decline. For details see Ionescu (2009). The default rate obtained in the model is produced keeping fixed the cost of college. Thus, given the same debt levels, obtaining a default rate lower than in the data is reasonable. In reality the debt burden has increased significantly. Also, I use as a reference point the cohort default rate in 2005 (which means the percentage of borrowers that defaulted by the end of the 2006 fiscal year), so that to abstract from the effects of the most recent recession. The default rate for student loans has increased to $7.09 \%$ in 2008 .
} 
Figure 5: Earnings Profiles for Defaulters versus Non-defaulters

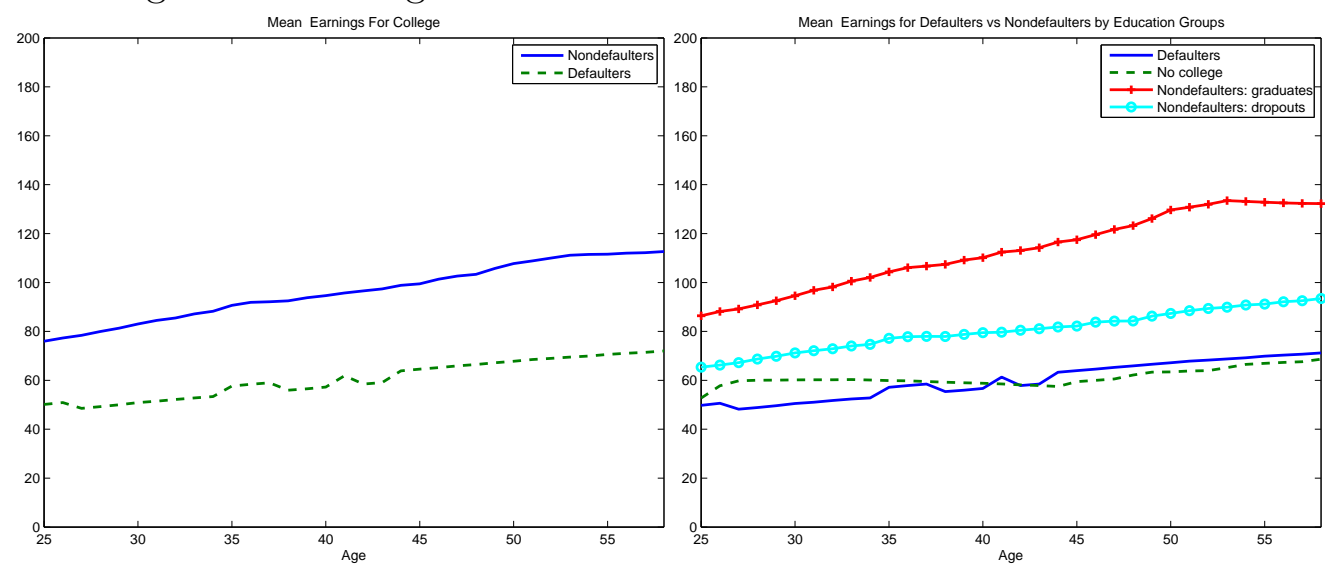

Table 7: Statistics of the Characteristics and Borrowing of Defaulters versus Non-defaulters

\begin{tabular}{|c|c|c|}
\hline Mean & Defaulters & Non-defaulters \\
\hline \hline Ability & $0.15(0.035)$ & $0.228(0.077)$ \\
\hline \hline Human Capital & $38.1(6)$ & $62.7(44)$ \\
\hline Assets & $2,610(3,840)$ & $9,900(10,320)$ \\
\hline
\end{tabular}

first 10 years in the life-cycle).

The combination of incentives for default and human capital accumulation over the lifecycle induced by different insurance mechanisms across individuals with different characteristics results in diverse effects for life-cycle earnings across education groups (see Figure 6). On the one hand, borrowers are relieved from payments during the default period under reorganization, a fact that allows them to supply less time to the labor market and invest more in human capital. While debt levels increase in the following period after default occurs, borrowers take advantage of the default opportunity by investing more in human capital in the period in which default occurs. This may increase their life-cycle human capital and earnings under reorganization, which is the case for college graduates. On the other hand, the possibility to discharge one's debt triggers income-contingent penalties and exclusion from borrowing. With a lower return to human capital, given the wage garnishment and no debt to repay, borrowers may take advantage of the default opportunity under liquidation to invest in their human capital, which increases their life-cycle human capital accumulation and earnings. However, part of this incentive may be reduced by the borrowing restriction, which is the case for college drop-outs. The model delivers that college graduates earn $0.3 \%$ more under reorganization than under liquidation while college drop-outs earn $2.8 \%$ less. Overall, the reorganization bankruptcy rule induces less human capital accumulation in the economy and slightly lower earnings over the life-cycle relative to the benchmark economy. 
Figure 6: Life-Cycle Earnings: Reorganization vs Liquidation

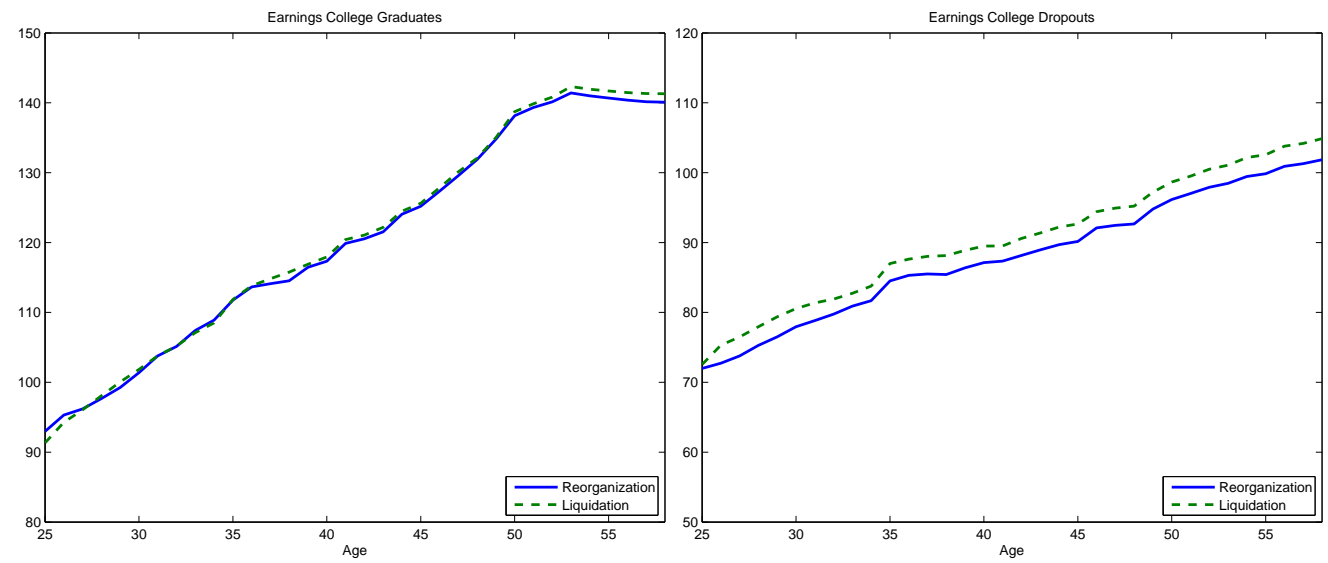

Lastly, changing the bankruptcy rule from liquidation to reorganization induces a change in the distribution of lifetime earnings in the economy with a slightly lower mean and a lower variance. This is a consequence of the shift in the distribution of characteristics across education groups, as documented above.

The experiment suggests that replacing liquidation with reorganization does not negatively affect college investment. At the same time, it delivers a lower default rate, and thus a lower cost from default in the economy. However, the option to discharge one's debt is quite valuable, and especially for college drop-outs, even if the penalties associated with this bankruptcy regime are severe. Overall, individuals earn slightly more in an economy where dischargeability is allowed. Motivated by these results, I study a policy that allows for partial dischargeability, which is limited to financially constrained individuals and does not trigger exclusion from the risk-free market. Results are presented in the next section.

\subsection{Partial Dischargeability}

I consider a policy that allows for dischargeability, but only after a sequence of payments is observed. The choice of my policy experiment is motivated by a recent bill that improves on an existing income-contingent repayment scheme (The Health Care and Education Reconciliation Act of 2010). This scheme requires borrowers to pay $15 \%$ of their discretionary income towards their loans. After 25 years, any remaining debt is discharged (i.e. forgiven). However, the option has been limited to special categories of borrowers, such as college graduates who teach, provide medical services in certain communities, or who provide military service. The recent bill reduces the monthly payment from $15 \%$ to $10 \%$ and accelerates the loan forgiveness from 25 years to 20 years, but only for new borrowers of new loans made on or after July 1, 2014. Also, the bill extends access to this plan to more borrowers regardless 
of their work place and major. 33

In this experiment, borrowers pay $10 \%$ of their income for 20 periods as long as their earnings are above the threshold of earnings considered for the wage garnishment penalty, $\underline{e}$. After 20 years, borrowers are excused from the rest of their debt. This arrangement limits dischargeability to borrowers with very high college debt and/or low earnings over the lifecycle. Unlike in the benchmark economy, in this experiment, the time when dischargeability of loans occurs is not a choice. Other important differences from the benchmark economy are that dischargeability does not trigger exclusion from the risk-free market and dischargeability happens later in life.

My findings show that this policy induces a substantial increase in the college enrollment rate, from $45.9 \%$ in the benchmark economy to $50.2 \%$, and produces a similar completion rate as in the benchmark $(46.3 \%)$. Consequently, the fraction of college-educated people is larger in this economy. Students borrow more compared to the benchmark $(\$ 16,580)$. Most of the increase in enrollment rates comes from students from the bottom quartile of ability $(+7.4 \%$ relative to benchmark), from students in the bottom quartile and medium quartiles (2 and 3 ) of human capital $(+7.5 \%$ and $+6.7 \%$, respectively relative to benchmark), and from students from the bottom quartile of assets ( $+8 \%$ relative to benchmark).

Students with relatively low levels of ability and human capital have low earnings levels and thus will pay small amounts each period towards their student loans. For any given level of debt, they are more likely to benefit from the dischargeability option in this economy. Thus, these borrowers discharge their debt, but without being forced out of the risk-free market as in the benchmark economy. Recall that this penalty is quite severe for borrowers with low levels of human capital. At the same time, students with low levels of assets are more likely to discharge their debt in the current policy. They have high debt levels, such that 20 periods of repayment may not be enough to pay the loan in full. The positive correlation in the model between initial characteristics makes the positive effects on college enrollment even stronger for these groups of individuals. In contrast, individuals with relatively high levels of human capital, ability and assets will not benefit from the option to discharge their loans. They will most likely repay their debt before the 20-period limit given that their debt-to-income ratio is quite low.

As a consequence of these effects, the characteristics of individuals across college and nocollege groups reverse. The average ability level for the college group is $2.3 \%$ lower relative to the no-college group (compared to $7 \%$ higher under liquidation). Human capital levels

\footnotetext{
${ }^{33}$ This policy resembles the repayment scheme that some countries, such as Australia and New Zealand have recently adopted. However, there is no loan forgiveness in these countries. Borrowers need to pay until the loan is paid in full (see Usher (2005)).
} 
are $9.2 \%$ lower for college students relative to no college (compared to $2.4 \%$ higher under liquidation). Finally, college students have similar levels of assets relative to the no-college group (compared to $21 \%$ higher under liquidation). However, given the characteristics of the new pool of people enrolled in college, the gap in individual characteristics between college graduates and college drop-outs increases.

As a result, earnings profiles in the economy are different in this environment. People who enroll in college in this economy earn $5 \%$ less, on average, relative to people who enroll in college in the benchmark economy. At the same time, people who choose not to enroll in college in this economy earn $4.2 \%$ more, on average, relative to people who do not enroll in college in benchmark. Overall, given a higher fraction of individuals who enroll in college, earnings are slightly higher in this economy relative to benchmark (by $0.3 \%$ ). However, individuals present a flatter profile compared to the benchmark economy, and especially for the college group. The incentives to invest in human capital earlier in life for the college group in the current economy is not as high as that of the college group in the benchmark economy.

\subsection{Welfare Considerations}

Whether a policy is judged as effective or not depends on the original objectives and social welfare. The policy change that I study came as a response to high default rates in the early 1990s. The rate has declined substantially since then with the policy potentially inducing lower default incentives. The policy, however, induces changes in human capital accumulation over the life-cycle and affects earnings. These effects differ across groups of students, as documented above.

I turn now to the welfare analysis, by using an aggregate welfare measure with agents being equally weighted. I evaluate the welfare implications of the policy change from liquidation to reorganization as well as welfare implications of the two policies: no default and partial dischargeability. With $W_{P o l}$ denoting total welfare in the case a policy change is implemented and $W_{B}$ denoting total welfare under the benchmark case, I quantify $\mu=\frac{W_{P o l}-W_{B}}{\left|W_{B}\right|}$. This measure is given in utility terms and represents the utility that makes agents indifferent between having the option to default on loans under liquidation and not having that option. Thus, $\mu>0$ implies a welfare gain if the liquidation regime is replaced with a different regime, otherwise the reverse is true. The total welfare measures are calculated by aggregating the value functions at time 1 across all agents in the economy. As mentioned, my evaluation accounts for budget neutrality, which implies different tax levels across economies with various bankruptcy arrangements. 
Table 8: Welfare Changes By Initial Characteristics

\begin{tabular}{|c|c|c|c|}
\hline Reorganization & Low & Medium & High \\
\hline \hline Ability & $+3.3 \%$ & $-0.1 \%$ & $-0.5 \%$ \\
\hline Human capital & $+1.8 \%$ & $+0.54 \%$ & $-0.47 \%$ \\
\hline Assets & $+1.5 \%$ & $+0.76 \%$ & $+0.8 \%$ \\
\hline \hline No default & \multicolumn{4}{|l}{} \\
\hline Ability & $+1.2 \%$ & $+0.1 \%$ & $+0.18 \%$ \\
\hline Human capital & $+1.5 \%$ & $+0.17 \%$ & $-0.25 \%$ \\
\hline Assets & $+1.4 \%$ & $+0.5 \%$ & $+0.3 \%$ \\
\hline Partial dischargeability & \multicolumn{4}{|}{} \\
\hline Ability & $+5.4 \%$ & $+1.2 \%$ & $-0.1 \%$ \\
\hline Human capital & $+5.2 \%$ & $+1 \%$ & $-0.25 \%$ \\
\hline Assets & $+5.3 \%$ & $+1.8 \%$ & $-0.2 \%$ \\
\hline
\end{tabular}

Numbers represent percentage changes relative to the benchmark.

Overall, the model delivers a welfare improvement of $1.2 \%$ under the reorganization regime relative to the liquidation regime. On the one hand, the possibility to discharge one's debt gives a relief in repayment, but it comes with a cost on defaulters: part of their wage is garnished and they are prevented from borrowing in the risk-free market for 10 periods. In addition, the government raises higher taxes in the benchmark economy to cover the cost from discharged debt. This cost is paid by everyone in the economy. These effects differ across education groups such that college drop-outs are better off under the liquidation regime whereas the other education groups are better off under the reorganization regime.

Welfare effects vary significantly across groups of characteristics as Table 8 shows. The welfare improvement under reorganization is coming from the increase in welfare for people in the bottom quartiles of ability and human capital. This occurs for the following two reasons: first, most of these people do not enroll in college under either regime and thus they benefit from paying lower taxes under liquidation; and second, some of these people decide to enroll in college only under reorganization and thus have higher earnings. At the same time, people with high ability and human capital levels are worse off under reorganization. They enroll in college in large numbers and liquidating their debt is beneficial even if it comes with a penalty. The cost of being prevented from borrowing in the risk-free market is low for these types of borrowers.

My results show that in an economy where there is no default possibility, welfare improves by $0.35 \%$ relative to the benchmark case where the liquidation regime is in place. However, welfare is lower relative to the reorganization regime. On the one hand, with less insurance, people who enroll in college are worse off; on the other hand, they pay lower taxes, and thus their welfare increases (taxes are lower by $\$ 70$ per capita, per period (in 1984 dollars) 
compared to benchmark). Overall the cost to society associated with discharged debt is much larger compared to the benefit from using liquidation as an insurance mechanism. This result crucially depends on other forms of insurance that exist in the economy (such as labor supply and risk-free savings). The welfare effects differ by groups of people, with the poorest agents and agents with low levels of ability and human capital benefiting the most (see Table 8). These students enroll in college at low rates; thus not paying taxes for the cost of dischargeability out-weights the benefit of having the dischargeability policy in place. Note that there are no welfare losses relative to the benchmark economy except for the group with the highest level of human capital.

Finally, my findings suggest that a policy that requires repayments contingent on income and allows for partial dischargeability improves welfare by $2.8 \%$ relative to the benchmark economy. Individuals still have the option do discharge their debt under some circumstances; at the same time, they pay lower taxes given that the cost from discharged debt is much lower (taxes are lower by $\$ 55$ per capita, per period compared to benchmark). Poor individuals with low ability and human capital benefit the most from this policy. Some of these individuals do not enroll in college in either benchmark economy or in the economy with partial dischargeability; thus, they simply benefit from paying lower taxes. Some of these individuals, however, decide to enroll in college when partial dischargeability is allowed; thus, in addition to benefiting from paying lower taxes, they benefit from earning more relative to benchmark. They will most likely discharge their debt given low repayments for 20 periods and high indebtedness. Consequently welfare benefits are quite substantial for these groups of people. At the same time, rich individuals with high levels of ability and human capital incur welfare losses from this policy. These individuals will most likely not discharge their debt under the current economy, given their high repayments per period and low levels of debt. However, given their relatively high levels of ability, they have high incentives to invest in their human capital after college. Thus, the option to discharge their debt (relatively soon after college) in the benchmark economy allows them to pursue further investments in human capital. Recall that, for this group of people, exclusion from borrowing is not severe given relatively high levels of human capital. They can smooth consumption by supplying more labor, which is highly rewarded in the market.

To conclude, the policy that changed bankruptcy rules from liquidation to reorganization improves welfare; however effects differ significantly across groups of people. A policy that allows for partial dischargeability improves welfare even more, especially for individuals that are financially constrained in their ability to repay (borrowers with high indebtedness and low income). 


\section{Conclusion}

I developed a heterogeneous life-cycle stochastic economy with risky college investment that explains quantitatively and qualitatively the human capital investment behavior of different groups of high school graduates. Students may borrow under the student loan program and default on their loans after college. The model produces the observed profiles of earnings of high school graduates from the right distribution of initial characteristics. In addition, the model mandates the necessity of a correlation between assets and unobserved characteristics to deliver college enrollment and completion rates across income groups consistent with empirical findings.

The model predicts that college students have higher levels of ability and human capital stocks, on average, than high school graduates who do not enroll in college. College graduates have higher levels of ability and initial human capital stocks, on average than college dropouts. Findings suggest that ability drives the decision to enroll in college, while initial human capital stock is important for completing college. As a consequence of the diversity in human capital investment behavior across groups of different characteristics, the model delivers earnings profiles by education groups consistent with the data.

Results suggest that the option to discharge one's debt helps reduce the risk of investing in college, even though this option comes with a cost. In an economy, where default and dischargeability is not allowed, enrollment in college declines by $1.9 \%$, with most of the decline coming from students with low levels of assets, high ability and medium levels of human capital. These are individuals who value the option to discharge the most, and at the same time, are not severely affected by exclusion from borrowing. Overall, dischargeability benefits college drop-outs.

A reorganization bankruptcy rule that implies no dischargeability of loans, but also no exclusion from borrowing seems as effective as the liquidation regime in inducing college investment. Reorganization produces the same college enrollment and completion level as under liquidation. The rule reduces default rates significantly, but also investment in human capital after college. Overall people invest less in their human capital and earn slightly less over the life-cycle under reorganization. These effects differ across individuals: there is a shift in the distribution of college students such that the gap in characteristics between education groups shrinks. Consequently, college drop-outs earn less under reorganization than under liquidation, whereas the opposite is true for college graduates.

Given that the cost of dischargeability is quite high, which translates into higher taxes in a liquidation regime, welfare increase by $1.2 \%$ in reorganization compared to liquidation. Under reorganization, individuals with low levels of human capital, ability, and assets, who 
typically do not enroll in college, are better off, whereas individuals with relatively high levels of ability, human capital and assets are worse off. A policy that allows for income-contingent repayments and partial dischargeability that is restricted to financially constrained borrowers, improves welfare even more, by $2.8 \%$ relative to liquidation.

To conclude, my results show that dischargeability benefits students from relatively low income backgrounds, but with relatively high levels of college preparedness. The cost associated with this policy, however, is high. Replacing it with alternative rules such as reorganization or partial dischargeability may be desirable on welfare grounds. However, effects vary significantly across individuals with different characteristics. The interaction between institutionalized insurance mechanisms, such as various bankruptcy regimes for student loans and self-insurance mechanisms, such as endogenous labor supply and borrowing in other markets proves to be crucial when analyzing quantitative effects on human capital investment.

\section{References}

Athreya, K. (2002). Welfare implications of the bankruptcy reform act of 1999. Journal of Monetary Economics 49(8), 1567-1595.

Athreya, K., X. Tam, and E. Young (2009). Unsecured credit markets are not insurance markets. Journal of Monetary Economics 56(1), 83-103.

Attanasio, O., H. Low, and V. Sánchez-Marcos (2005). Female labor supply as insurance against idiosyncratic risk. Journal of the European Economic Association 3(2-3), 755-764.

Autor, D., F. Levy, and R. Murnane (2003). The Skill Content of Recent Technological Change: An empirical exploration*. Quarterly Journal of Economics 118(4), 1279-1333.

Becker, G. (1964). Human Capital: A Theoretical and Empirical Analysis with Special Reference to Education. The University of Chicago Press, Chicago.

Ben-Porath, Y. (1967). The producation of human capital and the life-cycle of earnings. Journal of Political Economy.

Braxton, J., A. Hirschy, and S. McClendon (2003). Understanding and Reducing College Student Departure. Jossey-Bass, San Francisco.

Browning, M., L. Hansen, and J. Heckman (1999). Handbook of Macroeconomics. Eslevier Science B.V Amsterdam. 
Cabrera, A., A. Nora, and M. Castaneda (1993). College Persistence: Structural Equations Modeling Test of an Integrated Model of Student Retention. Journal of Higher Education $64(2)$.

Cameron, S. and C. Taber (2004). Estimation of Educational Borrowing Constraints Using Returns to Schooling. Journal of Political Economy 112(1), 132-182.

Carneiro, P. and J. Heckman (2002). The evidence on credit contraints in post secondary schooling. The Economic Journal 112(482), 705-734.

Caucutt, E. and K. Kumar (2003). Higher education subsidies and heterogeneity: A dynamic analysis. Journal of Economic Dynamics and Control 27(8), 1459-1502.

Chatterje, S., D. Corbae, M. Nakajim, and J. Rios-Rull (2007). A quantitative theory of unsecured consumer credit with risk of default.

Chatterjee, S. and F. Ionescu (2010). Insuring College Failure Risk. Working paper, FRB Philadelphia.

College Board (2009). Trends in student aid. College Board Publication.

Cunha, F. and J. Heckman (2009). The Economics and Psychology of Inequality and Human Development. Journal of the European Economic Association 7(2-3), 320-364.

Cunha, F., J. Heckman, and S. Navarro (2005). Separating uncertainty from heterogeneity in life cycle earnings. Oxford Economic Papers 57(2), 191.

Dynarsky, M. (1994). Who defaults on student loans? Findings for the national postsecondary student aid study. Economic of Education Review 13(1), 55-68.

Ehrlich, I. and J. Kim (2007). The Evolution of Income and Fertility Inequalities over the Course of Economic Development: A Human Capital Perspective. Journal of Human Capital 1(1), 137-174.

GAO (2003). Student Loan Programs. U.S. General Accounting Office.

Garriga, C. and M. Keightley (2007). A General Equilibrium Theory of College with Education Subsidies, In-School Labor Supply, and Borrowing Constraints. Federal Reserve Bank of St. Louis Working Paper, 207-051.

Gross, J., O. Cekic, D. Hossler, and N. Hillman (2009). What Matters in Student Loan Default: A Review of the Research Literature. Journal of Student Financial Aid 39(1), 19-29. 
Heathcote, J., K. Storesletten, and G. Violante (2009). Quantitative macroeconomics with heterogeneous households. NBER Survey.

Heckman, J., L. Lochner, and P. Todd (2003). Fifty years of Mincer earnings regressions. NBER Working Paper.

Hendricks, L. and T. Schoellman (2009). Student Abilities During the Expansion of US Education, 1950-2000. Working Paper.

Huggett, M., G. Ventura, and A.Yaron (2006). Human capital and earnings distribution dynamics. Journal of Monetary Economics 53(2).

Ionescu, F. (2008). Consolidation of student loan repayments and default rates across income groups. The B.E. Journal of Macroeconomics 8(1). Topics.

Ionescu, F. (2009). Federal Student Loan Program: Quantitative Implications for College Enrollment and Default Rates. Review of Economic Dynamics 12(1), 205-231.

Johnson, M. (2009). Borrowing Constraints, College Enrollment, and Delayed Entry. Working paper.

Kaplan, G. (2009). Moving back home: Insurance against labor market risk. International Monetary Fund Working Paper.

Keane, M. and K. Wolpin (2001). The effect of parental transfers and borrowing constraints on educational attainment. International Economic Review.

Krueger, D. and F. Perri (2006). Does income inequality lead to consumption inequality? evidence and theory1. Review of Economic Studies 73(1), 163-193.

L. Berkner, S. H. and E. F. Cataldi (2002). Descriptive Summary of 1995-96 Beginning Postsecondary Students: Six Years Later. National Center for Education Statistics 2003151.

Livshits, I., J. MacGee, and M. Tertilt (2007). Consumer bankruptcy: A fresh start. The American Economic Review 97(1), 402-418.

Lochner, L. and N. Monge (2010). The Nature of Credit Constraints and Human Capital. American Economic Review. Forthcoming.

Lucas, D. and D. Moore (2007). The student loan consolidation option: An analysis of an exotic financial derivative. Technical report, CBO Working Paper.

Manski, C. (1983). College Choice in America. Harvard University Press. 
Meghir, C. and L. Pistaferri (2004). Income variance dynamics and heterogeneity. Econometrica 72(1), 1-32.

Mincer, J. (1974). Schooling, Experience, and Earnings. Human Behavior \& Social Institutions No. 2. NBER.

Mincer, J. (1997). The production of human capital and the life cycle of earnings: Variations on a theme. Journal of Labor Economics 15(1), 26-47.

Murphy, K. and F. Welch (1992). The structure of wages. The Quarterly Journal of Economics 10\%, 285-386.

Restuccia, D. and C. Urrutia (2004). Intergenerational Persistence of Earnings: The Role of Early and College Education. The American Economic Review 94(5), 1354-1378.

Rubinstein, Y. and Y. Weiss (2006). Post schooling wage growth: Investment, search and learning. Handbook of the Economics of Education 1, 1-67.

Stinebrickner, R. and T. Stinebrickner (2008). The Effect of Credit Constraints on the College Drop-Out Decision: A Direct Approach Using a New Panel Study. American Economic Review 98(5), 2163-2184.

Stinebrickner, T. and R. Stinebrickner (2009). Learning about Academic Ability and the College Drop-out Decision. NBER Working Paper.

Storesletten, K., C. Telmer, and A. Yaron (2001). How Important Are Idiosyncratic Shocks? Evidence from Labor Supply. The American Economic Review 91(2), 413-417.

Storesletten, K., C. Telmer, and A. Yaron (2004). Consumption and risk sharing over the life cycle* 1 . Journal of Monetary Economics 51(3), 609-633.

Sullivan, T., E. Warren, and J. Westbrook (2001). The fragile middle class: Americans in debt. Yale Univ Pr.

Usher, A. (2005). Global Debt Patterns: An International Comparison of Student Loan Burdens and Repayment Conditions.

Volkwein, J., B. Szelest, A. Cabrera, and M. Napierski-Prancl (1998). Factors Associated with Student Loan Default among Different Racial and Ethnic Groups. Journal of Higher Education 69(2).

Willis, R. and S. Rosen (1979). Education and Self-Selection. Journal of Political Economy $87(5), 7-36$. 


\section{A Appendix}

\section{A.1 Data details}

This section presents several more important facts about college investment and financing in the U.S. that guide my modeling choice. Facts are based on my findings from the Beginning Postsecondary Survey (BPS 95/96) and the Baccalaureate and Beyond Survey (BB 92/93) as well as on various reports. All numbers are provided in constant 1982-1984 dollars.

The BPS 95/96 collects data on intensity of college attendance, performance during college years and completion status of post-secondary education programs for students who enrolled in college in 1995. Follow-up surveys are conducted in 1998 and 2001. I consider students who enroll in four-year colleges, exclusively full-time in their first academic year, and without delay following high school graduation. The BB 92/93 collects data on students who received their bachelor's degrees in 1992-93 with follow-up surveys in 1994 and 1997.34

According to the BPS 95/96 data, $68.5 \%$ of students who enroll in college full-time in 95/96 choose to go to four-year colleges. This percentage has increased since then. According to the College Board (2009), $73 \%$ of full-time undergraduates enroll in four-year colleges. Furthermore, the report documents that $93 \%$ of federal loans were granted to students enrolled in four-year institutions.

College investment is risky, with dropout rates between $37 \%$ and $50 \%$ in the U.S. In my BPS sample, the dropout rate is $38 \%$ defined as the fraction of students in the sample who, in 2001, report not having earned a bachelor's degree. Also, my findings from the BPS data show that the majority of students drop out from college later rather than sooner: out of all college drop-outs, only $11 \%$ of college students leave college in the first 3 years of college and $89 \%$ during their 4 th year in college or later. These are students who report having last enrolled in academic years 1995-96, 1996-97 or 1997-1998 and never acquired a bachelor degree (at any institution). The average completion time for my sample is 4.13 years and the average enrollment time is 3.4 four-years. 35

To estimate the probability of completion in my model, I look at completion rates by cumulative GPA during college. Completion rate is defined as the fraction of students who have earned a bachelor's degree by June 2001. Findings show that $7 \%$ of students with grades C and D graduate from college, 30\% of students with mostly Cs graduate, $45 \%$ of students with mostly Bs and Cs graduate, $56 \%$ of those with mostly Bs graduate, $67 \%$ of students

\footnotetext{
${ }^{34}$ Most of my findings are based on the BPS 95/96 given the richness of this data set. Occasionally, I use the BPS 90 data that surveys students who enroll in college in 1990. However, the last follow-up survey for the BPS 90 is in 1994.

${ }^{35}$ For the timing of dropping out by student's SAT scores, see Chatterjee and Ionescu (2010).
} 
with mostly Bs and As graduate, and $70 \%$ of college students with mostly As graduate from college. The distribution of grades in the sample is $0.7,6.4,19.4,35,28.8,9.5$.

My BPS analysis also indicates that $58.8 \%$ of students work in college and this fraction is larger among college drop-outs: $64.4 \%$ of college drop-outs work during college and $55.8 \%$ of graduates work. Overall, $34.3 \%$ of college students work more than 15 hours $(37.1 \%$ of drop-outs and $27.2 \%$ of graduates).

According to the National Center for Education Statistics (NCES) data, the cost for attending college in 1986-1990 was $\$ 37,471$ for private universities and $\$ 15,340$ for public universities 36 This cost includes tuition and fees, books and supplies, room and board, transportation and personal expenses. Among the students enrolled, $67 \%$ went to public and $33 \%$ to private universities. The enrollment-weighted average cost in 1986-1990 is $\$ 22,643$. The direct college expenditure in 1986-1990 represents $35 \%$ of the full college cost at public universities and $67 \%$ at private universities. The enrollment weighted average of tuition cost per each year in college is $\$ 2,977$. Costs have increased recently at a very fast pace (College Board (2009)).

College students use several sources to finance their college education. Based on a 2008 study by Sallie Mae and Gallup of undergraduate students and their parents, parents contribute nearly half $(48 \%)$ of the total amount paid for college, most of which comes from parental income and savings. Students are paying 33\% of the cost, most in the form of loans. Some part, however, comes from students' income and savings. The remaining college costs are covered by grants and scholarships (15\%) and contributions by friends and relatives (3\%).

According to the College Board (2009), 66\% of 2007-08 bachelor's degree recipients graduated with student loans and the average college debt among graduating seniors was $\$ 23,186$ (excluding PLUS Loans but including Stafford, Perkins, state, college and private loans), the majority of which comes from federal sources. Loans under the FSLP are based on financial need and are subsidized by the government. 37 Students are eligible to borrow up to the full college cost minus expected family contributions (EFC). Currently under the FSLP there exists a limit on student loans (of $\$ 23,000$ ). In the 1990, the year of interest for the current study, the proportion of students who borrowed is also significant (around 54-60\% depending on surveys); on average, students borrowed $\$ 10,258$. According to a report from the NCES (2004a) the loan limit binds for a significant fraction of borrowers in the recent years (50\%), whereas in the early 1990 s that was not the case. 38

\footnotetext{
${ }^{36}$ Source: U.S. Department of Education, National Center for Education Statistics, Digest of Education Statistics, 1995; and Projections of Education Statistics to 1979-80.

${ }^{37}$ The FSLP consists in both subsidized and unsubsidized loans. Research shows, however, that all government loans are heavily subsidized (see Lucas and Moore (2007)).

${ }^{38}$ Source: The Condition of Education 2004: Paying for College; Changes Between 1990 and 2000 for
} 
The EFC is the amount students and families are expected to contribute to the price of attendance at a post-secondary institution. The EFC is calculated using federal need analysis methodology and takes into account dependency status, income, assets, number of siblings also in college, and other related factors. The formula is designed to compare ability to pay across families to promote the equitable distribution of available aid.

According to a NCES report (2004b), the average EFC for full-time, full-year students in $99-00$ was $\$ 11,020$; the report notes that the EFC remained roughly constant over time. 39 My findings from the BPS 95/96 show that the average EFC for four-year full-time students is $\$ 8,265$. I also find that the $\mathrm{EFC}$ is higher for graduates than for drop-outs (12,216 vs $8,826)$. The EFC is higher for students who do not take out loans (15,870 vs 8,015$)$. I also look at this measure in the 1990 BPS data and find that the mean for the EFC is $\$ 9,585$ and the standard deviation is $\$ 10,798$. I use these later values for my calibration, given several changes in computing the EFC formula, which were introduced in 1992 by the amendments to the Higher Education Act. ${ }^{40}$

According to the BPS 95/96 data, 51\% of students enrolled in four-year college borrow to invest in their college education, whereas only $17 \%$ of students enrolled in two-year colleges borrow for college. The average loan size (federal loans, both subsidized and unsubsidized) is $\$ 10,258$ for the four-year group and $\$ 6,215$ for the two-year group. Similar values are obtained from the NCES report (2004b). According to the survey, 36\% of college students attending four-year colleges received loans, whereas $15.2 \%$ of college students attending twoyear colleges received student loans. Also, the survey reports an average loan amount of $\$ 8,623$ for college students at public colleges and of $\$ 11,108$ for borrowers at private colleges; this delivers an average of $\$ 9,413$ for all borrowers that attend four-year colleges. The average for the borrowers who attend two year colleges is $\$ 3,353$.

Finally, according to the NCES report (2004b), 12\% of college students, on average, received merit-based aid over the past several years, the major source being institutional aid. Using the B\&B 92/93 data set, I find that the amount of merit based aid received increases by GPA quartiles with an average of $12 \%$ of the total cost for the bottom GPA quartile and an average of $63 \%$ of the total cost for the top GPA quartile. On average, merit aid represents almost $33 \%$ of the cost of college.

Full-Time Dependent Undergraduates. NCES 2004-075

${ }^{39}$ Source: Wei, C.C., Li, X., and Berkner, L. (2004). A Decade of Undergraduate Student Aid: 1989-90 to 1999-2000 (NCES 2004-158). U.S. Department of Education, National Center for Education Statistics. Washington, DC: U.S. Government Printing Office.

${ }^{40}$ The HEA (1992) no longer included home equity in assets used to calculate the EFC. Also, assets are no longer counted for parents with incomes under $\$ 50,000$ who file a short federal tax form. The annual minimum student contribution was eliminated and the required contribution from student earnings was reduced. 


\section{A.2 Life-Cycle Earnings and Distribution of Characteristics}

Figure A-1: Statistics of Earnings Profile: Model vs Data
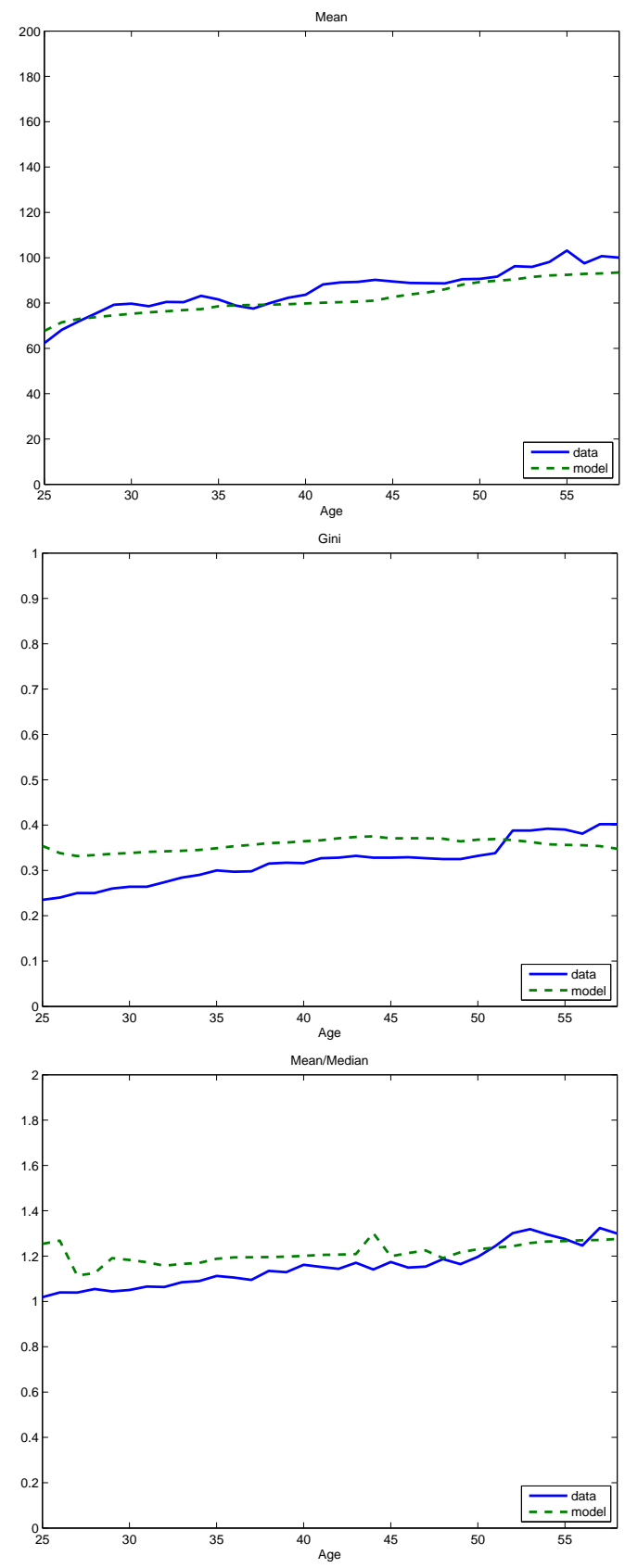

Note: Earnings levels are normalized such that the mean of earnings for high school graduates in the last period equals 100 . This normalization translates into $\$ 30,000$ (1982-1984 dollars). 
Figure A-2: Marginal Densities

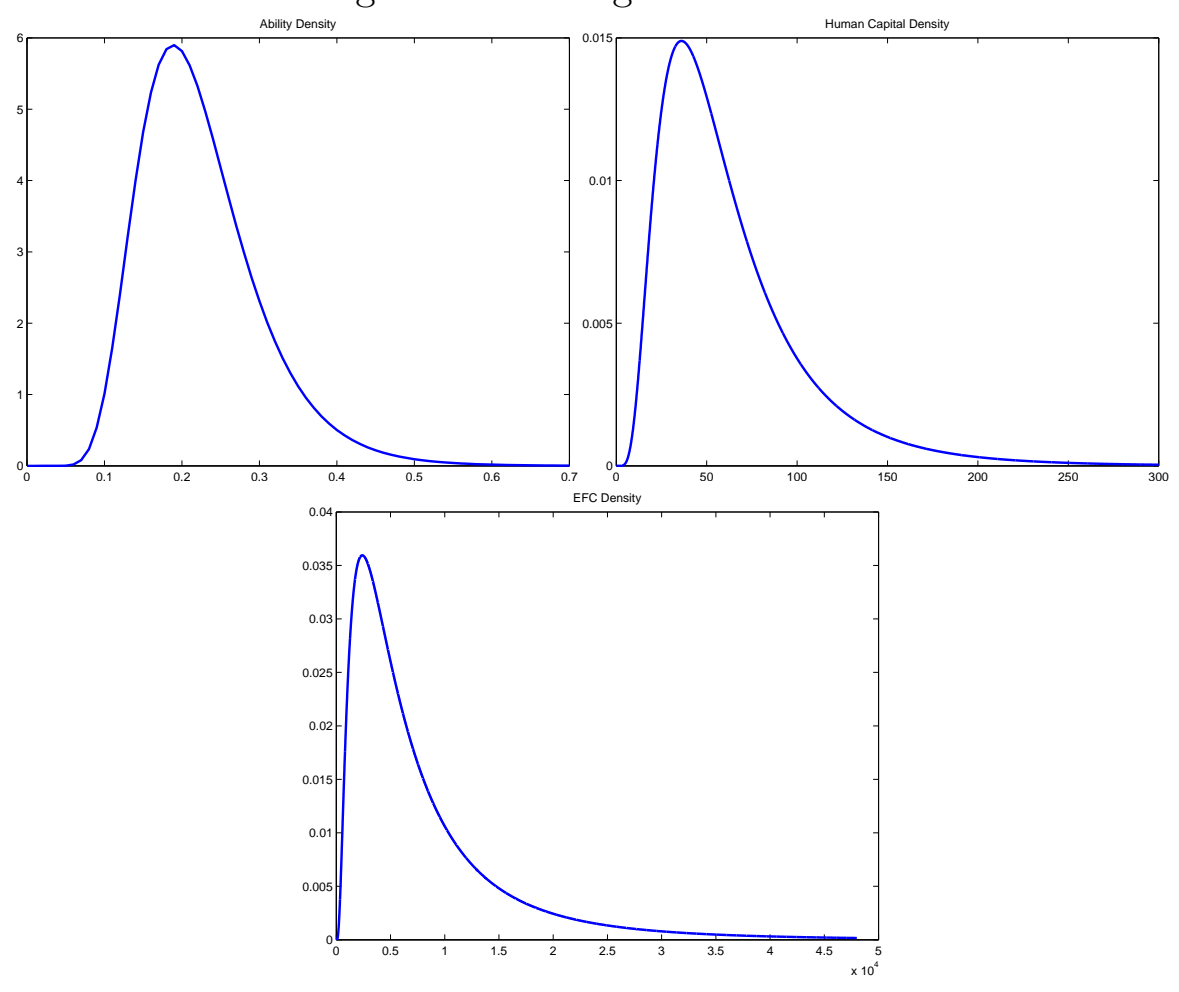

Figure A-3: Life-Cycle Earnings By Education Group: Data vs Model
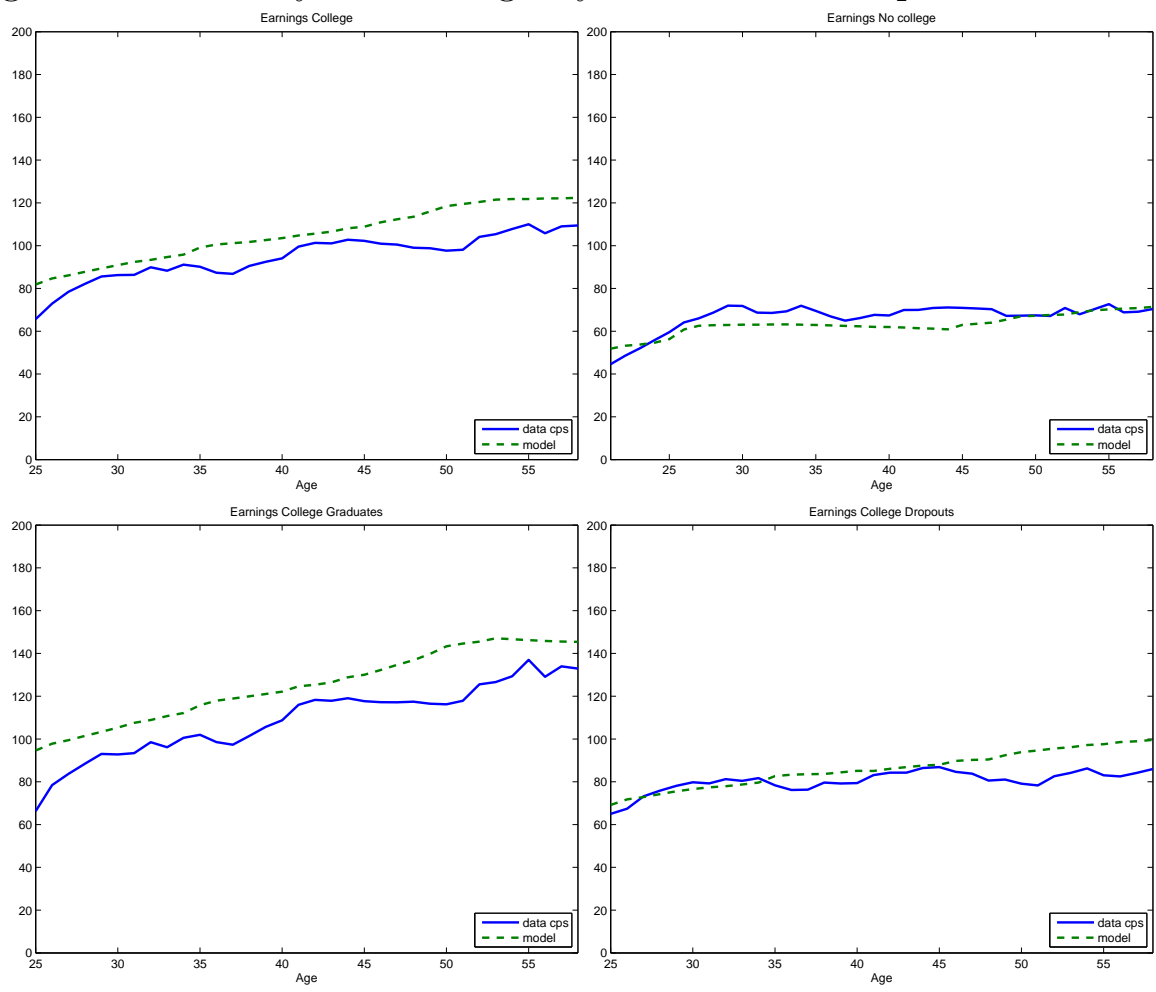